\title{
Factor Intensity, Product Switching, and Productivity: Evidence from Chinese Exporters*
}

\author{
Yue $\mathrm{Ma}^{\dagger}$ \\ Lingnan University
}

\author{
Heiwai Tang $\ddagger$ \\ Tufts University
}

\author{
Thes University
}

October, 2012

\author{
Yifan Zhang $\S$ \\ Lingnan University
}

\begin{abstract}
This paper analyzes how a firm's specialization in its core products after exporting affects its factor intensity and productivity. Using Chinese manufacturing firm data over the period of 1998-2007, we find that firms become less capital-intensive but more productive after exporting, compared to non-exporters that share similar ex ante characteristics. To rationalize these findings that contrast with existing studies, we develop a variant of the model by Bernard, Redding, and Schott $(2010,2011)$ to consider firms producing multiple products with varying capital intensity. The model predicts that when a firm in a labor-abundant country starts exporting, it specializes in its core competencies by allocating more resources to produce labor-intensive products. Firm ex ante productivity is associated with a smaller decline in capital intensity after exporting. A sharper post-exporting decline in capital intensity is associated with a larger increase in measured total factor productivity. We find firm-level evidence supporting these predictions. Using transaction-level data for the period over 2000-2006, we find that Chinese exporters continuously add new products that are less capital-intensive than their existing products and drop those that are more capital-intensive.
\end{abstract}

Key Words Exporters, Productivity, Factor Intensity, Multi-product Firms

JEL Classification Numbers: F11, L16, O53

${ }^{*}$ We would like to thank Daniel Berkowitz, Loren Brandt, Chang-Tai Hsieh, Amit Khandelwal, Steven Klepper, Alexis Leon, Soiliou Namoro, Marc Muendler, Albert Park, Veronica Rappaport, Thomas Rawski, Stephen Redding, Peter Schott, Robert Staiger, Jo Van Biesebroeck and seminar participants at the Berkeley-Booth-IGC China Summer Institute 2011, Clemson, IFPRI, Johns Hopkins SAIS, LSE, NBER ITI Meetings, Penn-State-Tsinghua Conference, World Bank, and UIUC, for their helpful comments and discussions. The authors gratefully acknowledge funding from Competitive Earmarked Research Grant (LU3409/06H) of the RGC of HKSAR Government and Direct Allocation Grant of Lingnan University (funding \# DR07B4). The usual disclaimer applies.

†yuema@ln.edu.hk.

${ }^{\ddagger}$ heiwai.tang@tufts.edu.

§yifan.zhang@ln.edu.hk. 


\section{Introduction}

A large body of research has documented the superior performance of exporters relative to nonexporters. Exporters are found to be larger, more productive, more capital- and skill-intensive (e.g. Bernard and Jensen, 1999). Existing explanations for exporters' superior performance can be categorized into three broad themes, namely self-selection (e.g., Clerides et al., 1998; Bernard et al., 2003; Melitz, 2003), learning by exporting (e.g., Aw et al., 2000; Van Biesebroeck, 2005; De Loecker, 2007), and firms' investment or skill upgrading in preparation to export (e.g., Bernard and Jensen, 1997; Yeaple, 2005; Lileeva and Trefler, 2010; Bustos, 2011; Aw et al., 2011; Iacovone and Javorcik, 2012).

This paper studies a lesser known effect of exporting on firm performance - how a firm's specialization in its core products after exporting affects its factor intensity and thus productivity. Using a large panel data set of China's manufacturing firms over the 1998-2007 period, we find that firms' measured productivity increases but capital intensity declines after exporting. Figures 1 (unbalanced panel) and 2 (balanced panel) show that exporters' average capital intensity was persistently lower than that of non-exporters in China from 1999 to 2007. Figure 3 shows the kernel densities of capital intensity for both types of firms in 2007, after demeaning the firm measures from the industry averages. It shows that exporters are less capital-intensive in a distribution sense. We systematically confirm that these patterns are observed within firms and within a narrowly defined industry. To address the bias due to firms' selection into exporting, we use the matched sampling techniques to compare exporters and non-exporters with similar ex ante observable characteristics (i.e., Heckman, Ichimura, and Todd, 1997 and the subsequent studies). By comparing ex post characteristics of exporters and the matched non-exporters within the same bins based on ex ante productivity, capital intensity, and sales, we continue to find results consistent with Figures 1-3.

Should we be surprised about these results? Perhaps we should if we compare our results with the existing evidence about the superior performance of exporters relative to non-exporters (e.g., Bernard and Wagner, 1997; Bernard and Jensen, 2004; Van Biesebroeck, 2005; and De Loecker, 2007). On the other hand, our results serve as a "mirror image" of the findings by Bernard, Jensen, and Schott (2006), who find that US manufacturing firms in sectors facing more import competition from low-wage countries are more likely to switch industries and become more skill and capitalintensive over time. We find that firms in China, a large low-wage country, exhibit the opposite pattern in capital intensity when they start exporting. During the sample period when Chinese exports surged, we find that their exporters exploited the country's comparative advantage by consistently maintaining a lower capital intensity than non-exporters. These findings, which can be viewed as the Heckscher-Ohlin effects within firms, have important implications for understanding 
the impact of trade on the factor markets in developing countries and their trade partners. ${ }^{1}$

What accounts for the fact that firms become less capital-intensive after exporting? To answer this question, we develop a variant of the multi-product model by Bernard, Redding, and Schott (2010, 2011) (BRS hereafter) to consider both capital and labor as factors of production. In the model, heterogeneous firms can potentially produce a continuum of products, for which production differs in capital intensity. Besides firm heterogeneity in productivity ("ability") as in Melitz (2003), a firm's profitability of selling a product in a foreign market depends on a set of exogenous firmproduct "consumer taste" attributes. In addition to the country-specific fixed export cost, exporting an additional product entails extra fixed costs (e.g. R\&D expenditure to produce a blue print or overhead costs to manage a product-specific sales team). Thus, a firm exports a product only if its product attribute guarantees sufficiently high revenue to cover the extra fixed export cost. Given China's labor abundance, labor-intensive products are associated with lower zero-profit thresholds than capital-intensive products for all firms on average. When a firm receives a favorable shock to its fixed export cost so that it starts exporting (to a capital-abundant country), it will specialize in its core competencies - the labor-intensive products. Thus, a firm becomes more labor-intensive after exporting either by expanding sales of existing labor-intensive products (the intensive margin) or by adding the more labor-intensive products (the extensive margin).

Besides rationalizing the findings about exporters' lower capital intensity, our model yields two additional predictions. First, it sheds light on how changes in product scope would affect a firm's measured TFP. In particular, firms that have a larger reallocation of resources from capital-intensive to labor-intensive products after exporting have a bigger increase in measured TFP. The reason is that given fixed export costs and firm productivity, an increase in the sales of labor-intensive products implies a larger degree of increasing returns, relative to capital-intensive products. Second, our model also predicts that the ex ante more productive exporters experience less product churning and have a smaller decline in capital intensity after exporting. We find supporting evidence for both of these theoretical predictions using the firm-level data. Although recent studies on multi-product firms have made similar predictions, to the best of our knowledge, this paper is the first study to provide empirical evidence on the impact of trade on firm productivity through the proposed product churning channel. ${ }^{2}$ Our findings provide a new angle to interpret the relation between exporting and firm productivity, both ex ante and ex post, in addition to the existing empirical

\footnotetext{
${ }^{1}$ Notice although Bernard, Redding, and Schott (2007) also incorporate a Heckscher-Ohlin framework with the Melitz (2003) model, firms only differ in terms of productivity but not factor intensity within an industry, which is what we focus on.

${ }^{2}$ Bernard, Redding, and Schott (2010) and Mayer, Melitz, and Ottaviano (2012) theoretically show that specialization in core competencies can enhance measured firm productivity. They do not provide direct empirical evidence verifying these predictions.
} 
studies that mainly focus on learning by exporting or selection.

To provide further evidence that product churning is the channel through which exporters in labor-abundant countries can potentially become less capital-intensive after exporting, we use transactions-level trade data. By merging the trade data with the manufacturing firm data, we are able to compute the weighted average of capital intensity of each product (HS 6), based on the capital intensity measures of the firms producing the product. With the product-level capital intensity measures, we investigate whether firms' product churning patterns are consistent with our model predictions: firms would specialize in labor-intensive products after exporting. Using transaction-level data for the period over 2001-2006, we find that new exporters in China continuously add new products that are less capital-intensive than their existing products and drop those that are more capital-intensive. The added products tend to be even less capital-intensive if the destination country is more capital-abundant.

The rest of the paper is organized as follows. Section 2 reviews the related literature. Section 3 describes our data source. Section 4 explores the basic patterns of export participation, capital intensity, and productivity. Section 5 examines the impact of exporting on new exporters' capital intensity. Section 6 presents a theoretical model to rationalize our findings. Sections 7 and 8 examine the specific theoretical predictions using transactions-level trade data. The last section concludes.

\section{Related Literature}

Our paper relates to several strands of literature. First and foremost, it contributes to the growing theoretical literature on multi-product exporters. A common feature of this literature is that diversification across products is costly, and access to foreign markets provides an opportunity for firms to specialize in their core competencies. Feenstra and Ma (2008) study how trade liberalization reduces firms' product scope due to the presence of cannibalization effects. Nocke and Yeaple (2008) study the implications when a firm's marginal cost of production increases in product scope due to managers' limited span of control as in Lucas (1978). Eckel and Neary (2010) examine theoretically how exports can enhance firm productivity when multi-product firms specialize in their core competencies, taking advantage of the larger market size. In their model, each firm has a core product that is associated with the lowest marginal cost. Producing a product farther away from the firm's core product is increasingly more costly. Bernard, Redding, and Schott (2011) show theoretically that trade liberalization would result in both within and across-firm reallocation of resources, leading to growth in both firm and aggregate productivity. The added 
multi-product dimension permits firms to drop products that are less appealing to the consumers and add those that are more appealing upon trade liberalization, raising measured firm productivity. Using Brazilian firm data, Arkolakis and Muendler (2011) document the within-firm pattern of specialization in core competencies and rationalize the findings by multi-product model that features local entry costs, which increase in the firms' product scope. Mayer, Melitz, and Ottaviano (2012) go further by showing the relation between destination market toughness and exporters' product mix. They show theoretically and empirically that firms increase sales of the best-performing products in tougher markets.

All these papers highlight the positive impact of exporting on firm productivity through the product churning channel, but do not provide direct empirical evidence supporting that. Using the change in capital intensity after exporting to capture the degree of specialization, we provide evidence on how product churning contributes to a higher measured firm productivity. Moreover, we extend the existing multi-product framework that largely focuses on a single factor of production to consider both capital and labor as inputs, and empirically verify that specialization in core competencies (labor-intensive products for exporters in developing countries) is associated with a higher observed firm productivity. ${ }^{3}$

Second, our paper contributes to the extensive literature on the productivity effects of exporting. One strand of this literature hypothesizes that exporters can learn from foreign buyers about product designs and advanced production technology (World Bank, 1993; De Loecker, 2007). Firmlevel empirical studies find mixed results for this learning-by-exporting hypothesis. Clerides, Lach, and Tybout (1998) and Bernard and Jensen (1999) are among the first studies to empirically distinguish the causal impact of exporting on productivity and self-selection into exporting. They find that exporters have higher productivity than non-exporters before exporting but not after. ${ }^{4}$ Other studies find more positive results (e.g., Wagner, 2002; Girma, Greenway, and Kneller, 2003; Alvarez and Lopez, 2005; Van Biesebroeck, 2005; and De Loecker, 2007). ${ }^{5}$ On the other hand,

\footnotetext{
${ }^{3}$ In the appendix of Bernard, Redding, and Schott (2010), the authors extend the baseline model to consider two factors of production. They further show how endogenous product choices upon export participation affect firm measured productivity. They did not, however explicitly solve for how relative factor endowment of the exporting country can serve as a source of within-firm comparative advatange. Our later discussion on specialization in core comptetence and productivity gains are developed on their argument.

${ }^{4}$ Clerides, Lach, and Tybout (1998) use firm-level from Colombia, Mexico, and Morocco for their study; while Bernard and Jensen (1999) use firm-level data from the U.S. Aw, Chung, and Roberts (2000) and Delgado, Farinas, and Ruano (2002) come to the same conclusions for Taiwan, Korea, and Spain.

${ }^{5}$ These studies include Wagner (2002) for Germany; Girma, Greenway, and Kneller (2003) for the United Kingdom; Alvarez and Lopez (2005) for Chile; Van Biesebroeck (2005) for sub-Saharan African countries; and De Loecker (2007) for Slovenia. A more recent study by a group of economists (International Study Group on Exports and Productivity, 2008) uses comparable firm panel data for 14 countries and an identical method to investigate the relationship between exports and productivity. They find strong evidence for self-selection but no evidence for learning-by-exporting. Specific to China, Kraay (1999) finds that exporters are more productive than non-exporters based on survey data over 2000 firms. Park et al. (2007) use exposure to the 1997 Asian financial crisis as an instrument and find that
} 
recent studies focus on the firms' decisions to simultaneously invest in technology and export. Among others, Lileeva and Trefler (2010) use the elimination of the U.S. tariffs as an instrument to predict Canadian firms' entry into the U.S. market, and show that access to foreign markets enhances labor productivity and technology adoption for the less productive firms. Similarly, Bustos (2011) find that Argentine firms experiencing sharper tariff cuts in Brazil increase investment in process innovation more. Aw, Roberts, and Xu (2011) structurally estimate a dynamic model that examines the complementary effects of exporting, investment in technology, and firm productivity. We side-step from the relations between investment, trade, and productivity, and focus instead on an independent channel through which specialization in core products after exporting can affect a firm's productivity.

Third, as is mentioned in the introduction, our paper is related to the existing studies that consistently find exporters to be more capital- or skill-intensive (e.g., Bernard and Wagner, 1997; Bernard and Jensen, 2004; Van Biesebroeck, 2005; and De Loecker, 2007). While most of these studies are silent about the specific channels through which exporting affects firms' factor intensity, the conventional wisdom in the literature is that only the most productive firms select into exporting or that firms invest to upgrade their product quality or production technology before exporting. To the extent that firms' capability is positively correlated with skill or capital intensity (e.g., Yeaple, 2005; Harrigan and Reshef, 2012) or investments are skill and capital-biased (e.g., Verhoogen, 2008), the literature about the productivity premium of exporters can be readily used to explain higher capital and skill intensity of exporters. Notice that our findings of lower capital intensity among Chinese exporters should not be taken as a rejection to the investment hypothesis. What our findings imply is that the product churning channel we propose potentially dominates the investment and selection mechanisms in China, which leads to a net decline in capital intensity among exporters.

\section{Data}

For our empirical analysis, we use two data sets - manufacturing firm panel data and customs transactions-level data. The firm data are from the annual surveys of industrial firms conducted by China's National Bureau of Statistics (NBS) over the 1998-2007 period. The surveys cover all state-owned firms and all non-state-owned firms with sales above 5 million yuan (about 0.6 million USD during the sample period). ${ }^{6}$ The data set contains detailed information for about 100 balanceexports causally raises productivity of Chinese firms that export to developed countries.

${ }^{6}$ The unit of analysis is a firm, and not the plant, but other information in the survey suggests that more than $95 \%$ of all observations in our sample are single-plant firms. 
sheet variables, including firm ID, address, ownership, output, value added, four-digit industry code (about 480 categories), six-digit geographic code, exports, employment, original value of fixed asset, and intermediate inputs. The firms in our sample account for $57 \%$ of total industrial value added in 1998 and $94 \%$ in 2007. Since we focus on manufacturing, mining and utility industries are excluded from our sample. Moreover, we delete observations with missing values for key variables and those that fail to satisfy some basic error checks. ${ }^{7}$ The cleaned data set provides an unbalanced panel of firms that increases in coverage from 148,685 firms in 1998 to 313,048 in 2007.

We use unique numerical IDs to link firms in the sample over time. Firms occasionally receive a new ID as a result of restructuring, merger, or acquisition. Where possible, we aim to track firms as their boundaries or ownership structures change, using information on the firm's name, industry, address, etc., to link them. ${ }^{8}$ These other matches are still important as one-sixth of all firms that are observed for more than one year experience a change in their official ID over the period of analysis.

In the later part of the paper, we also use transactions-level trade data from China Customs that cover all transactions of Chinese exporters and importers over 2000-2006. The trade dataset provides information on import and export values, quantities, and prices between China and over 200 destination countries at the HS 6-digit level for each trading firm, by ownership of enterprise (out of 9 types, e.g. state owned, foreign invested, Sino-foreign joint ventures), and customs regime (ordinary trade and processing trade). ${ }^{9}$ As an example, Table A5 in the appendix shows the HS 6-digit products within the industry of "footware, gaiters, \& the like" (HS2 = 64). The purpose of using this data set is to study product churning and within-firm dynamics after a firm starts exporting. We merge the manufacturing firm data with the transactions-level trade data based on firm names. ${ }^{10}$ Statistics about the merging are reported in Table A4 in the appendix. We use the merged data set to identify new exporters in the trade data set, and compute the measures of capital intensity at the product level (HS6). ${ }^{11}$ Details about the steps to compute the product-level

\footnotetext{
${ }^{7}$ Some firms have missing observations for variables needed to calculate productivity. This arises either because the information was not originally reported, or because of negative values for variables such as the real capital stock or value added. Following Jefferson, Rawski and Zhang (2008), we drop all firms with less than 8 employees as they fell under a different legal regime. As a result, $17 \%$ of firms in the the original data set are dropped from the sample in 1998 , but the fraction drops to $6 \%$ in each year after 2001 .

${ }^{8}$ The fraction of firms in a year that can be linked to a firm in the previous year increases over time from $84.5 \%$ in the first two years (1998-1999) to $92.2 \%$ in the final two years (2006-2007). Overall, 95.9\% of all year-to-year matches are constructed using firm IDs, and $4.1 \%$ using other information on the firm.

${ }^{9}$ The data also report quantity, quantity units, customs offices (ports) where the transaction was processed (97 in total), and transportation modes.

${ }^{10}$ Depending on the year, $37-48 \%$ of export value in the trade data set is successfully merged to the NBS firm data set. $70 \%$ of exporters in NBS is merged.

${ }^{11}$ To the best of our knowledge, Bernard, et al. (2010) are the only group of researchers who did the same data construction before. They compute the measures of factor intensity at the SIC 5-digit level for the US, and find substantial within-sector (2-digit) heterogeneity in capital and skill intensity.
} 
capital intensities are provided in Appendix A.3.

A firm's real output and value added are deflated by a sector-specific ex-factory price index. ${ }^{12}$ Real wages are calculated using consumer price index. ${ }^{13}$ A firm's capital intensity is defined as the real value of capital stock per worker.

Since capital intensity is the focus of this paper, it is crucial to measure both firm capital and labor accurately. Firms do not report fixed investment. For capital stock, the NBS data only report the original value of fixed asset (OVFS) and net value of fixed asset (NVFS). OVFS is the total capital stock at original purchase prices, and NVFS is equal to OVFS less accumulated depreciation. Thus, OVFS and NVFS are the sum of nominal values of different years. To deal with this problem, we follow the recent estimation method in Brandt, Van Biesebroeck, and Zhang (2011). The idea is to use information from the founding year of a firm to estimate the firm's initial capital stock. Then we apply perpetual inventory method and calculate firm real capital stock in each year. In this procedure, we assume a depreciation rate of $9 \%$ and deflate nominal fixed investment using the deflators constructed in Perkins and Rawski (2008). ${ }^{14}$ A firm's nominal fixed investment is the observed change in OVFS. To test the robustness of our results, we also use the NVFS deflated by industry-specific investment price index as an alternative measure of real capital stock.

As an attempt to adjust for the quality of workers employed by a firm, we use total wage bill instead of employment to compute an alternative measure of labor. The problem with wages is that it is likely to underestimate the total employee compensation which should also include employee supplementary benefits. In our data, labor's share of value added is only 34 percent, which is much lower than 55 to 60 percent suggested by national income accounting. ${ }^{15}$ The magnitude of such underestimation may vary across different ownership, region and year. Therefore, we decide to use employment as our primary measure for labor and only use total wage bill for robustness check.

To deal with the biases arising from endogenous input choices, we adopt the Levinsohn and Petrin (2003) procedure that uses intermediate inputs as a proxy for unobservable productivity shocks. ${ }^{16}$ For reasons that will become clear below, exporters and non-exporters can have different factor intensity of production within a disaggregated sector. We thus assume different sector-specific production functions for exporters and non-exporters respectively to estimate firm productivity. ${ }^{17}$

\footnotetext{
${ }^{12}$ Ex-factory price refers to the price at the factory, and does not include any other charges, such as delivery or subsequent taxes.

${ }^{13}$ The price indices are from China Statistical Yearbook, various issues.

${ }^{14}$ Please see the appendix of Brandt, Van Biesebroeck and Zhang (2011) for more details.

${ }^{15}$ Hsieh and Klenow (2009) discover the same issue in the same data set. They assume that the non-wage benefits are a constant fraction of a plant's wage bill, with the adjustment factor chosen so that the wage plus non-wage compensation equal to half of China's aggregate value added.

${ }^{16}$ The Levinsohn-Petrin procedure is implemented in this paper using the Stata module "levpet" developed by Petrin, Levinsohn and Poi (2004).

${ }^{17}$ In the early version of the paper, we extend the Levinsohn-Petrin procedure by incorporating the firm's export
} 
In this paper, a non-exporter is a firm that never exported up to and including the reporting year. New exporters are firms that did not export in the previous years in the sample but started exporting in the year of analysis. Their pre-export characteristics can therefore be matched with those of the non-exporting firms. Existing exporters are firms that have export records in previous years, or firms that start exporting already in their first year of the sample. When we do matching, this group of firms is dropped because there is no pre-exporting characteristics for these firms by definition. We do include these existing exporters in the fixed effects regression analysis, which we will discuss immediately below.

\section{Basic Patterns}

Table A1 in the appendix reports the key statistics of new exporters, continuing exporters, and non-exporters, respectively for the odd years in our sample. For each group of firms, we further separate the sample into domestic, which include state-owned and private firms, and foreign firms. Among domestic firms, the fraction of exporters fluctuates between 16 and 24 percent (continuing exporters and new exporters combined), which is similar to the US where roughly 20 percent of plants exported in 1992 (Bernard, Eaton, Jensen, and Kortum, 2003). Similar to the U.S. firms, over 80 percent of domestic new exporters also sell domestically in China; and about half of the domestic new exporters derive less than 10 percent of the revenue from foreign sales. In China, there is a significant difference between domestic firms and foreign-invested enterprises in terms of the prevalence of exporters. Foreign firms overwhelmingly engage in exporting, with the fraction of exporters ranging between 63 percent (in 1999) and 72 percent (in 2004).

To compare the difference in capital intensity and productivity between exporters (new and continuing exporters combined) and non-exporters, we estimate the following specification:

$$
\ln S_{i}=\beta E_{i}+\gamma_{0}+\{F E\}+\varepsilon_{i}
$$

where $S_{i}$ can be firm $i$ 's TFP or capital intensity. $E_{i}$ is a dummy variable indicating the firm's export status. $\{F E\}$ stands for a host of fixed effects. $\gamma_{0}$ is a constant and $\varepsilon_{i}$ is the error term. The percentage differential in $S_{i}$ between exporters and non-exporting firms can be calculated from the estimated coefficient as $100 \times(\exp (\beta)-1)$.

In Table 1, Panel A shows the estimates of equation (1) with $\ln (\mathrm{TFP})$ as the dependent vari-

decision into the productivity estimation procedure to control for the export endogeneity problem (Van Biesebroeck, 2005; De Loecker, 2007), instead of estimating productivity using separate production functions for exporters and non-exporters, respectively. The results obtained were qualitatively similar. 
able. ${ }^{18}$ Column (1) includes $E_{i}$ and year fixed effects, while column (2) also includes industry and province fixed effects. To make sure that the change is not driven by unobserved firm characteristics, in column (3) we include firm fixed effects (along with year fixed effects). We find that exporters are on average more productive than non-exporters. These results about the productivity gap are consistent with most findings in the existing literature, and contrast with the findings by $\operatorname{Lu}(2010) .{ }^{19}$

In columns (4) and (5), we find that the productivity premium of exporters is mostly determined by the productivity variation among domestic private firms. Foreign exporters do not appear to be more productive than foreign non-exporters. ${ }^{20}$ By splitting the sample into the pre-WTO period (1999-2001) and the post-WTO period (2002-2007), column (6) and (7) show that the TFP premium of exporters is larger before China's accession to the WTO than after (decreased from 0.13 to 0.07 $\log$ points).

Next, we present results on the gap in capital intensity between exporters and non-exporters. Existing studies consistently find that exporters are more capital-intensive (e.g., Bernard and Wagner (1997) for Germany, Bernard and Jensen (2004) for the US, Van Biesebroeck (2005) for SubSaharan Africa, and De Loecker (2007) for Slovenia.). In sharp contrast, we find that exporters in China are less capital-intensive than non-exporters. Specifically, in Panel B of Table 1, when capital intensity is measured as the ratio of real capital stock to employment (our preferred measure that is computed based on the perpetual inventory method proposed by Brandt, Van Biesebroeck, and Zhang, 2011), we find in column (2) that exporters are about 5 percent less capital-intensive than non-exporters within a four-digit industry (480 industries). Notice that the capital intensity gap more than doubles for domestic private firms than for foreign firms (columns (5) and (6)).

When a firm's real capital stock is measured as the average net value of fixed assets deflated by the industry-specific investment price index (Panel C), or when capital intensity is measured using a firm's total wage bill instead of employment as the denominator (Panel D), exporters still appear to be less capital-intensive than non-exporters. The capital intensity gap is significantly

\footnotetext{
${ }^{18} \ln (\mathrm{TFP})$ is estimated using the Levinsohn and Petrin (2003) procedures. We separately estimate each sector's production function for exporters and non-exporters, respectively. Firm productivity is the residual for each firm from the estimation.

${ }^{19}$ The difference between our resulsts and $\mathrm{Lu}$ (2010) can arise from the fact that she focuses on labor productivity while we focus on TFP. Since we show that exporters tend to be less capital-intensive, we believe that the change in capital intensity can contribute to the observed lower labor productivity within a narrowly defined industry. Notice that our results are consistent with Dai, Miatra, and Yu (2012) who show that once processing firms, which tend to be more labor-intensive, are taken out from the sample, exporters still appear to have higher labor productivity.

${ }^{20}$ Our findings that foreign exporters exhibit no superior productivity echo those by Baldwin and Gu (2003), who also find no productivity premium among foreign exporters in Canada. These results lend support to the productivitysorting prediction by Helpman, Melitz, and Yeaple (2004), who show theoretically that only the most productive firms engage in foreign direct investment. Another explanation is that foreign firms come with experience and knowledge in serving foreign markets. The potential to learn by exporting is limited.
} 
larger when the latter measure is used. A possible reason is that using total wage bill to compute capital intensity partially adjusts for the quality of the firm's workforce. Recent studies show that exporters are larger and tend to employ more skilled workers. This may explain why exporters' capital intensity will be even lower when it is denominated by effective labor units. To conserve space, we focus on the results based on capital intensity measured by the perpetual inventory method (i.e., the Panel B measure). Since using the wage-bill-based capital intensity measure tends to give us a wider capital intensity gap between exporters and non-exporters, the results reported in the rest of the paper can be considered as a lower bound of the change in capital intensity after exporting. Attempts to adjust for the quality of workers should yield quantitatively larger results.

Given China's comparative advantage in labor-intensive goods, it may not seem surprising that exporters in China are less capital-intensive than non-exporters at first sight. However, since this pattern is found within disaggregated industries at the 4-digit level (about 480 industries), the standard factor-proportions theory of trade that emphasizes between-sector reallocation of resources cannot explain within-industry heterogeneity in factor intensity. Given the novelty of these findings, we will devote most of the rest of the paper on explaining this pattern. We will develop a theoretical model to rationalize the findings, and discuss the linkages between capital intensity and productivity, both before and after firms' exporting.

\section{Changes in capital intensity for new exporters}

Let us now compare the change in factor intensity between non-exporters and new exporters,

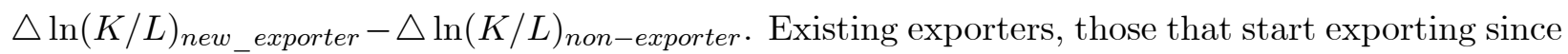
the beginning of the sample, are always excluded from this analysis. As a first pass, we follow Lileeva and Trefler (2010) to compare firms within a quartile bin (4 on each dimension) based on firm TFP and capital intensity in the previous year (16 bins in total). In Table 2, the first column in Panel A shows that new exporters in the lowest quartile of TFP experience an average of 0.048 (average across all four entries in the column) log-point decline in capital intensity after exporting relative to non-exporters within the same TFP quartile. The difference is significant at the $1 \%$ level. As we move to higher TFP quartiles (moving to the right in each row), we continue to find a post-exporting decline in capital intensity, but the decline is smaller the higher the TFP quartile is. The average drop in capital intensity (relative to non-exporters) is only 0.028 log points in the highest TFP quartile. We will empirically confirm and theoretically explain this negative relationship between firms' ex ante TFP and post-exporting drop in capital intensity. 
The first row in Panel A shows that among the firms in the lowest quartile of $\ln (K / L)$, the average drop in $\ln (K / L)$ after exporting is 0.021 log-points relative to the non-exporters in the same quartile. We find a larger relative post-exporting decline in $\ln (K / L)$ for firms with ex ante higher $\ln (K / L)$. In the highest $\ln (K / L)$ quartile, the decline increases to 0.058 log points. We will also empirically confirm and theoretically explain this pattern.

Panel B repeats essentially the same analysis but instead of allocating firms into four TFP quartile bins, we separate the sample into high and low TFP groups. Then within each group, we further divide the firms into small and large firms based on firm total sales. The reason of doing this cut is to address the concern that the estimates of TFP using the Levinsohn-Petrin approach may not accurately capture a firm's productivity, due to measurement errors, heterogeneous production functions across ownership types, and so on. As is reported, within each TFP bin, there is no obvious difference in the relative decline in capital intensity between small and large firms. However, the difference between high and low TFP groups of firms is still obvious.

In addition to putting firms into bins to compare firms with similar characteristics, we apply the propensity-score matching estimator proposed by Rosenbaum and Rubin (1984) and applied by Heckman, Ichimura, and Todd (1997) in the program evaluation literature to match firms with ex ante similar characteristics (see Appendix A.1 for details). ${ }^{21}$ We first estimate the propensity score of each firm based on a Probit model with the dependent variable equal to 1 if a firm starts reporting positive exports in the current year. We include a host of pre-exporting (previous-year) firm characteristics, including TFP, wage rate, capital intensity, firm age, firm sales (all in log), as well as industry, ownership, and year fixed effects as regressors. ${ }^{22}$ As an attempt to minimize the bias due to potentially omitting unobserved characteristics that may affect a firm's decision to start exporting, we do our matching within each of the 8 bins as defined in Panel B of Table 2, in the belief that firms within the same bin are not too different in terms of unobserved characteristics. ${ }^{23}$

Table 3 presents the estimation results of the post-exporting change in capital intensity using propensity-score matching techniques. In column (1), we find a significant decline in a firm's capital intensity in the year when it starts exporting, compared to non-exporters. This capital intensity gap is observed for all 8 combinations of productivity and capital-intensity bins considered in Panel B of Table 2. The gap is larger if the new exporter is ex ante more capital-intensive (bins 5-8), consistent with the results in Table 2. In columns (2)-(3), we split the sample into domestic firms,

\footnotetext{
${ }^{21}$ Previous studies have used the matching approach to search for causal effects of exporting on productivity, such as Wagner (2002), Girma, Greenaway, and Kneller (2003), Alvarez and Lopez (2005), Konings and Vandenbussche (2005), and De Locker (2007).

${ }^{22}$ Then local linear regression weights are constructed to match new exporters and never-exporters in each cell. Results are robust to using the nearest neighbor matching estimator.

${ }^{23}$ Alternatively, we estimate the Probit model industry by industry. The results about the capital intensity gap remains robust.
} 
which include state-owned enterprises and private firms, and foreign-invested firms for our analysis. We find the same pattern for both types of firms, with a larger drop in capital intensity observed in the domestic firm sample. In column (4), we measure capital stock simply as the net value of fixed assets deflated by the industry-specific investment price index. The results remain largely robust besides bins 3 and 4 . In the last column, we find a larger decline in capital intensity after exporting when total wage bill is used as the denominator to compute a firm's capital intensity, similar to the findings in Table 1.

\section{Theoretical Explanation}

To summarize, we have found robust evidence that a Chinese firm becomes less capital-intensive after exporting. We have used various methods - regressions including an exhaustive set of fixed effects, comparisons within bins, and matching within bins - to ensure the robutness of our results. Our findings contrast with the exiting literature that consistently shows higher skill and capital intensity for exporters. What could account for our seemingly puzzling findings for China? To answer this question, we construct a variant of the model by Bernard, Redding, and Schott (2010, 2011) (BRS hereafter). We first briefly discuss the set-up of the BRS model before elaborating in greater detail our extension. Readers are referred to the original paper for details.

Consumers consume a continuum of products with identical preferences: $U=\left[\int_{0}^{1} C_{s}^{\nu} d s\right]^{\frac{1}{\nu}}$, where $\kappa \equiv 1 /(1-\nu)>1$ is the elasticity of substitution between products. Within a product, firms produce horizontally differentiated varieties, facing their own demand. The consumption index for product $s, C_{s}$, takes the following form:

$$
C_{s}=\left[\int_{\omega \in \Omega_{s}}\left(\lambda_{s}(\omega) c_{s}(\omega)\right)^{\rho} d \omega\right]^{\frac{1}{\rho}}, 0<\rho<1
$$

where $\sigma \equiv 1 /(1-\rho)>1$ is the elasticity of substitution between varieties within a product. Following BRS, we assume that the elasticity of substitution between varieties within a product is larger than that between products $(\sigma>\kappa>1)$.

Firms are exogenously different along two dimensions, namely firm-specific "ability" and firmproduct-specific "consumer" appeals. More specifically, upon paying some fixed (sunk) costs to enter any market, a firm first draws its "ability", $\varphi \in[0, \infty)$, from a distribution $h(\varphi)$. $\varphi$ is firmspecific and is constant across countries and products. The firm then draws a set of "consumer taste" attributes for each potential product produced, $\lambda_{s} \in[0, \infty)$, from a distribution $g\left(\lambda_{s}\right)$. The 
set of $\lambda_{s}$ is firm-product specific and is constant across countries. ${ }^{24}$ To serve market $j$, either domestic or foreign, the firm has to pay an extra fixed cost $f_{j}$. In addition to $f_{j}$, a multi-product exporter needs to incur product-specific fixed costs, $f_{s j}$, for each product $s$ sold in market $j .{ }^{25}$ An exporter will export product $s$ to market $j$ when its $\lambda_{s}$ is sufficiently high to cover $f_{s j}$. As in BRS, the more productive exporters have a wider product scope, all else equal, as higher $\varphi$ generates positive profits even for products with low product attributes.

To rationalize our empirical results and derive a few more testable predictions regarding exporters' capital intensity, we modify the one-factor BRS model to consider two factors of production - capital and labor. Formally, firms have the following total cost function:

$$
T C_{s}=\left[f_{s}+\frac{q_{s}}{\varphi}\right] w^{1-\beta(s)} r^{\beta(s)}
$$

where $w$ and $r$ are the wage rate and the rental rate, respectively. We choose the wage as the numeraire (i.e., $w=1$ ). Notice that the fixed cost to produce a product is assumed to have the same factor shares as the variable costs. $\beta(s)$ represents capital intensity for product $s$. Without loss of generality, we rank product index $s \in[0,1]$ so that $\beta(0)=0, \beta(1)=1$, and $\beta^{\prime}(s)>0$ (i.e., capital intensity is increasing in product index $s$ ). Firm profit maximization implies the standard optimal price of a variety exported to country $j$ as

$$
p_{s j}=\frac{\sigma \tau_{j}}{\sigma-1} \frac{r^{\beta(s)}}{\varphi}
$$

where $\tau_{j}$ is the iceberg trade cost to country $j$. For simplicity, we assume that $\tau_{j}$ is identical for all products.

Consider two countries: China and destination country $j$. Country $j$ (for example, the U.S.) is assumed to be more capital-abundant than China. With trade frictions, factor prices would not be equalized across countries and the wage-rental ratio in country $j$ will be higher than that in labor-abundant China in equilibrium (i.e., $w_{j} / r_{j}>1 / r$ ). It can then be readily shown that the relative price of product $s$ between country $j$ and China, $\widetilde{P}_{j}(s)=P_{j}(s) / P(s)$, is decreasing in capital intensity (i.e., $\widetilde{P}_{j}^{\prime}(s)<0$ ) (see Appendix A.2 for details). ${ }^{26}$

Given that $\widetilde{P}_{j}(s)$ varies across products, an exporter has a different export portfolio to country $j$ compared to the domestic market, even when the set of product attributes $\left(\lambda_{s}\right)$ is identical for

\footnotetext{
${ }^{24}$ The main results of the model results will continue to hold if we assume that $\lambda_{s}$ is destination-product specific.

${ }^{25}$ Think of $f_{s j}$ as $\mathrm{R} \& \mathrm{D}$ expenditure required to produce a blue print for the product or the overhead costs to manage the product-specific sales team.

${ }^{26}$ A similar point has been made by $\mathrm{Lu}(2011)$ to rationalize why Chinese exporters are less productive than domestic producers in labor-intensive sectors.
} 
different destinations. ${ }^{27}$ Consider a firm with $\varphi$, the product attribute cutoff $\lambda_{s}^{*}(\varphi)$ for product $s$, above which the firm produces $s$ for domestic sales, is pinned down by the following zero-profit condition:

$$
\pi_{s}\left(\varphi, \lambda_{s}^{*}(\varphi)\right)=\frac{R_{s}}{\sigma}\left(r^{-\beta(s)} \rho P(s) \varphi \lambda_{s}^{*}(\varphi)\right)^{\sigma-1}-f_{s} r^{\beta(s)}=0
$$

where $\pi_{s}\left(\varphi, \lambda_{s}^{*}(\varphi)\right)$ represents the firm's profit by selling product $s$ domestically; $R_{s}$ stands for domestic aggregate expenditure spent on product $s . P(s)$ is the ideal price index for product $s .{ }^{28}$ Solving (4) gives us the firm-product specific consumer taste cutoff $\lambda_{s}^{*}(\varphi)$. Similarly, we can use the zero-profit condition for export sales of product $s$ to country $j$ to solve for the corresponding product attribute cutoff, $\lambda_{s j}^{*}(\varphi)$.

Importantly, for product $s$, the firm's product cutoff for exporting to $j$ equals

$$
\lambda_{s j}^{*}(\varphi)=\Phi_{j}(s) \lambda_{s}^{*}(\varphi)
$$

where $\Phi_{j}(s)=\tau_{j}\left(\frac{f_{s j}}{f_{s}} \frac{\widehat{P}_{j}}{\widehat{P}} \frac{R}{R_{j}}\right)^{\frac{1}{\sigma-1}}\left(\frac{P_{j}(s)}{P(s)}\right)^{-\gamma} \cdot \Phi_{j}(s)$ is increasing in variable $\left(\tau_{j}\right)$ and fixed export costs $\left(f_{s j}\right)$, as well as the relative aggregate price index of country $j\left(\frac{\widehat{P}_{j}}{\widehat{P}}\right) . \Phi_{j}(s)$ is increasing in $\frac{\widehat{P}_{j}}{\widehat{P}}$ because a higher $\frac{\widehat{P}_{j}}{\widehat{P}}$ results in a lower purchasing power of foreign consumers relative to domestic consumers. For the same reason, $\Phi_{j}(s)$ is decreasing in the total spending of country $j, R_{j}$. If countries are symmetric (i.e., $\widehat{P}=\widehat{P}_{j}, R=R_{j}$, and $\left.P_{j}(s)=P(s)\right), \Phi_{j}(s)=\tau_{j}\left(\frac{f_{s j}}{f_{s}}\right)^{\frac{1}{\sigma-1}} \geq 1$ when international trade costs are higher than domestic trade costs (i.e., $f_{s j} \geq f_{s}$ and $\tau_{j} \geq 1$ ). Given a product attribute, $\lambda_{s}, \Phi_{j}(s) \geq 1$ implies a weakly lower probability of exporting product $s$, conditional on positive domestic sales. Deviating from the symmetry assumptions, Bernard, Redding, and Schott (2009) and Lu (2011) postulate the possibility of having $\Phi_{j}(s)<1$ and study the resulting implications. ${ }^{29}$

If country $j$ is relatively more capital-abundant than China, $\frac{P_{j}(s)}{P(s)}$ is decreasing in $s$. Given the assumption that $\sigma>\kappa>1, \frac{\partial \Phi_{j}(s)}{\partial s}>0$. In words, all else being equal, a product attribute that guarantees profitable domestic sales is less likely to generate profitable export sales to $j$, the higher

\footnotetext{
${ }^{27}$ In BRS, there is a Poisson probability for the firm to draw firm-specific productivity term, and another Poisson probability that the firm draws a new consumer taste for a product. It is theoretically possible that a firm gets hit by a positive productivity shock and decides to export, while its product-specific consumer taste shocks do not change. Moreover, we follow BRS to assume that the distribution of abilities and product attributes are independent of one another.

${ }^{28}$ Specifically, consumers' utility maximization yields $R_{s}=\left[P(s)^{\frac{-\nu}{1-\nu}} / \int_{0}^{1} P(k)^{\frac{-\nu}{1-\nu}} d k\right] R$, where $R$ is total expenditure of the economy; $P(s)=\left[\int_{\omega \in \Omega_{s}} p(s, \omega)^{1-\sigma} d \omega\right]^{\frac{1}{1-\sigma}}$.

${ }^{29} \mathrm{In}$ particular, $\mathrm{Lu}(2011)$ finds that in labor-intensive sectors, Chinese exporters are on average less productive than non-exporters. Based on an extension of Bernard el al. (2007), she rationalizes the findings by postulating that if the domestic is more competitive than the foreign market, the domestic production cutoff can be lower than the export participation cutoff.
} 
the capital intensity of the product is.

Denote capital intensity (i.e., capital cost share) for product $s$ by $\theta_{s}=\frac{r k_{s}}{r k_{s}+w l_{s}}$, where $k_{s}$ and $l_{s}$ are the total amounts (including fixed cost of production) of capital and labor used to produce $s .{ }^{30}$ Capital intensity of a firm with productivity $\varphi$ serving only the domestic market is

$$
\Theta_{d}(\varphi)=\int_{0}^{1} \theta_{s} \widetilde{R}_{s}\left(\varphi, \lambda_{s}\right) I_{s}\left(\lambda_{s} \geq \lambda_{s}^{*}(\varphi)\right) d s=\int_{0}^{1}\left[\int_{\lambda_{s}^{*}(\varphi)}^{\infty} \theta_{s} \widetilde{R}_{s}\left(\varphi, \lambda_{s}\right) g\left(\lambda_{s}\right) d \lambda_{s}\right] d s
$$

where subscript $d$ denotes "domestic"; $I_{s}\left(\lambda_{s} \geq \lambda_{s}^{*}(\varphi)\right)$ is an indicator function, which equals 1 if $\lambda_{s} \geq \lambda_{s}^{*}(\varphi) . g\left(\lambda_{s}\right)$ is the stationary distribution of consumer tastes, which is discussed in detail in BRS. $\widetilde{R}_{s}\left(\varphi, \lambda_{s}\right)=\frac{R_{s}\left(\varphi, \lambda_{s}\right)}{R(\varphi)}$ is the ratio of the firm's product $s$ domestic sales to its total domestic sales. The last equality holds because of the law of large number: the firm's capital intensity is equal to the expected weighted average across all products' capital intensity.

Conditional on export participation in market $j$, we can derive the firm's capital intensity of the basket of goods exported to $j$ as

$$
\Theta_{j}(\varphi)=\int_{0}^{1} \theta_{s} \widetilde{R}_{s j}\left(\varphi, \lambda_{s}\right) I_{s}\left(\lambda_{s} \geq \Phi_{j}(s) \lambda_{s}^{*}(\varphi)\right) d s=\int_{0}^{1}\left[\int_{\Phi_{j}(s) \lambda_{s}^{*}(\varphi)}^{\infty} \theta_{s} \widetilde{R}_{s j}\left(\varphi, \lambda_{s}\right) g\left(\lambda_{s}\right) d \lambda_{s}\right] d s
$$

where $\widetilde{R}_{s j}\left(\varphi, \lambda_{s}\right)=\frac{R_{s j}\left(\varphi, \lambda_{s}\right)}{R_{j}(\varphi)}$ is the ratio of the firm's product $s$ sales in foreign market $j$ to the its total sales there. We assume that $\theta_{s}$ is identical for product $s$ in different markets. ${ }^{31}$ A firm selling both at home and country $j$ thus has the following capital intensity:

$$
\Theta_{d+j}(\varphi)=\left(1-\frac{R_{j}(\varphi)}{R(\varphi)+R_{j}(\varphi)}\right) \Theta_{d}(\varphi)+\frac{R_{j}(\varphi)}{R(\varphi)+R_{j}(\varphi)} \Theta_{j}(\varphi)
$$

As in BRS, given a continuum of products, the law of large number implies that a firm's exporting status is entirely determined by firm productivity, $\varphi$, and an overall fixed cost for exporting to country $j, f_{j}$. Given $\varphi$ and $\lambda_{s}^{*}(\varphi)$, firm expected profits from serving market $j$ is

$$
\pi_{j}(\varphi)=\int_{0}^{1}\left[\int_{\lambda_{s}^{*}(\varphi)}^{\infty} \pi_{s j}\left(\varphi, \lambda_{s}\right) g\left(\lambda_{s}\right) d \lambda_{s}\right] d s-f_{j}
$$

where $f_{j}$ is measured in labor in BRS, but is measured in domestic consumption bundle here.

\footnotetext{
${ }^{30}$ e.g. $r k_{s}=r k_{s}^{p}+r k_{s}^{f}$, where $k_{s}^{p}$ stands for the level of capital used for producing goods, while $k_{s}^{f}$ is the corresponding amount to cover the fixed cost of production, such as developing a blue print of the product.

${ }^{31}$ Recent literature has shown that within the same narrowly defined product category, product quality is higher for exports to richer destinations (Bastos and Silva, 2010; Manova and Zhang, 2012). If product quality is positively corrected with skill and capital intensity, as is shown by Verhoogen (2008), adjusting for the quality impact on factor intensity should strengthen our findings of lower capital intensity among exporters.
} 
Consider a firm that initially serves only the domestic market at period $t$ (i.e., $\pi_{j, t}(\varphi)<f_{j}$ ). Suppose a shock hits the firm and lowers its fixed export cost to $f_{j}^{\prime}$ such that $\pi_{j, t+1}(\varphi)>f_{j}^{\prime}$. The firm starts exporting to country $j$ at period $t+1 .^{32}$ For the moment, consider sufficiently high trade costs so that all product cutoffs for foreign sales are higher than the corresponding ones for domestic sales, $\Phi_{j}(s)>1$ or $\lambda_{s j}^{*}(\varphi)>\lambda_{s}^{*}(\varphi) \forall s .{ }^{33}$ Since $\frac{\partial \widetilde{\lambda}(s)}{\partial s}>0$, given the same distribution function $g\left(\lambda_{s}\right) \forall s$, the firm is more likely to have a $\lambda_{s}$ that is higher than both $\lambda_{s}^{*}(\varphi)$ and $\lambda_{s j}^{*}(\varphi)$ for labor-intensive (low- $s$ ) products. In other words, the firm is less likely to have $\lambda_{s}$ that justifies exports of capital-intensive (high $s$ ) products, even though the firm could be already selling the same product at home. Given a continuum of products, the (weighted) average capital intensity of the domestic product portfolio is the same before and after exporting (i.e., $\Theta_{d, t}(\varphi)=\Theta_{d, t+1}(\varphi)$ ). The (weighted) average capital intensity for the export bundle will be more labor intensive (i.e., $\left.\Theta_{j, t+1}(\varphi)>\Theta_{d, t+1}(\varphi)\right)$. In sum, we have the following proposition:

Proposition 1 A firm's capital intensity $\Theta(\varphi)$ after switching from non-exporting at period $t$ to exporting to a capital-abundant country at period $t+1$ satisfies the following inequality:

$$
\Theta_{j, t+1}(\varphi)<\Theta_{t+1}(\varphi)<\Theta_{d, t+1}(\varphi)=\Theta_{t}(\varphi)
$$

where $\Theta_{t}(\varphi)$ and $\Theta_{t+1}(\varphi)$ are the capital intensities of the firm before and after exporting. $\Theta_{d, t+1}(\varphi)$ and $\Theta_{j, t+1}(\varphi)$ are the capital intensities of the domestic and foreign baskets of products after exporting.

Given the definition of firm capital intensity in eq. (6), Proposition 1 provides an explanation to our empirical findings that firms become less capital-intensive after exporting to a capital-abundant country. Notice that Proposition 1 does not require an assumption that $\lambda_{s j}^{*}(\varphi)>\lambda_{s}^{*}(\varphi) \forall s$. For it to hold, what we need is simply $\frac{\partial \Phi_{j}(s)}{\partial s}>0$. In fact, we can do the same exercise as Lu (2011) and assume that there exists $\bar{s}(\varphi)<1$ such that $\lambda_{s j}^{*}(\varphi) \leq \lambda_{s}^{*}(\varphi) \forall s \leq \bar{s}(\varphi)$, and $\lambda_{s j}^{*}(\varphi)>\lambda_{s}^{*}(\varphi)$ otherwise. In Appendix A.3, we show that as long as there are some $s$ with $\lambda_{s j}^{*}(\varphi)>\lambda_{s}^{*}(\varphi)$, $\frac{\partial \Phi_{j}(s)}{\partial s}>0$ suffices to guarantee a decline in capital intensity of a new exporter serving $j$.

Based on the intuition behind Proposition 1, we have the following corollary about the relationship between destinations' capital abundance and exporters' capital intensity.

\footnotetext{
${ }^{32}$ A firm can also switches from non-exporting to exporting after receiving a favorable shock to productivity, $\varphi$. With a few mild assumptions, our main theoretical results will go through. Since our empirical analysis has focued on comparing exporters and non-exported with similar ex-ante characteristics, including productivity, we choose to focus on the case of fixed-cost shocks to more closely link our theory to the empirical results.

${ }^{33}$ Bernard et al. (2007) make a similar assumption - the productivity cutoffs to export are higher in both capitaland labor-intensive sectors.
} 
Corollary 1 Between two ex ante identical firms, the one that starts exporting to a country that is more capital-abundant but identical otherwise will experience a larger decline in capital intensity.

\section{Proof: See Appendix A.2.}

The idea is that when a firm exporting to a more capital-abundant country, the product cutoff $\Phi_{j}(s)$ is increasing faster in $s$. Furthermore, for the other aspects of the destination countries to be identical, there must exist a product $\widetilde{s} \in(0,1)$ such that $\Phi(\widetilde{s})=\Phi_{j}(\widetilde{s}), \Phi_{j}(s) / \Phi(s)<1 \forall s<\widetilde{s}$ and $\Phi_{j}(s) / \Phi(s)>1 \forall s>\widetilde{s}$. As such, there are two margins of adjustment at which a new exporter will end up with a lower capital intensity. The first margin is the intensive margin - firms will increase sales of the existing labor-intensive products after exporting. The second margin is the extensive margin - firms will also add products that have $\lambda_{s}$ satisfying $\lambda_{s}^{*}(\varphi)>\lambda_{s}>\Phi_{j}(s) \lambda_{s}^{*}(\varphi)$ to the export product portfolio but not the domestic product portfolio. ${ }^{34}$ Notice that this situation is more likely to happen for labor-intensive products as $\frac{\partial \Phi_{j}(s)}{\partial s}>0$. Adjustments at either margin implies an increase in the share of labor-intensive products in the firm's product portfolio, contributing to a decline in its capital intensity.

Our model focuses only on product churning to explain the changes in a firm's factor intensity. By no means that this is the only channel through which exporting can affect an exporter's factor intensity. Firms may still invest in new capital or capital-intensive activities, as is shown by some existing studies (e.g., Aw et al., 2011; Bustos, 2011). It is worth noting that our empirical results show a net effect of exporting on capital intensity, which postulate perhaps the standard investment effects proposed in the literature is dominated by the product-churning effects in China. Importantly, our model is general enough to incorporate the investment decisions considered by those studies and examine the gross effects of product churning in other developing countries as well.

Besides rationalizing the main findings of the paper, our model yields additional predictions that will be empirically examined below. First, our model shows that $\lambda_{s}^{*}(\varphi)$ is decreasing in $\varphi$ for all $s$. In other words, more productive firms have lower product cutoffs for both domestic and foreign sales and can afford to sell a wider range of products in any given market. Thus, ex ante more productive firms are expected to have less product churning and thus a smaller decline in capital intensity after exporting. Using the same firm-level data, we will examine the following proposition.

\footnotetext{
${ }^{34}$ Different from BRS, exporting does not result in product dropping here. In BRS, firms drop products in general equilibrium when trade liberalization increases competition in the domestic market.
} 
Proposition 2 An ex ante more productive firm experiences a smaller decline in capital intensity $\Theta_{t+1}(\varphi)$ after exporting. Formally,

$$
\frac{\Theta_{t+1}(\varphi)}{\Theta_{t}(\varphi)}<\frac{\Theta_{t+1}\left(\varphi^{\prime}\right)}{\Theta_{t}\left(\varphi^{\prime}\right)}<1 \quad \text { if } \varphi^{\prime}>\varphi
$$

\subsection{A Note about the Revenue-based Productivity Estimates}

Our empirical results show that domestic firms become more productive after they start exporting. It is important to understand how changes in product scope after exporting, conditional on $\varphi$, can contribute to the observed productivity gain. To this end, we derive the revenue-based productivity measure associated with domestic sales of product $s$ as:

$$
\mu_{s}=\frac{R_{s}\left(\varphi, \lambda_{s}\right)}{x\left(\varphi, \lambda_{s}\right)}
$$

where $x\left(\varphi, \lambda_{s}\right)=\Gamma_{s} l\left(\varphi, \lambda_{s}\right)^{1-\beta(s)} k\left(\varphi, \lambda_{s}\right)^{1-\beta(s)}$ is the associated input bundle, and $\Gamma_{s}$ is a sectorspecific constant that delivers a cost function equal to equation (3). By expressing the quantity produced as $q_{s}\left(\varphi, \lambda_{s}\right)=\varphi\left(x_{s}\left(\varphi, \lambda_{s}\right)-f_{s}\right)$, we can rewrite $(7)$ as:

$$
\mu_{s}=\frac{r^{\beta(s)}}{\rho}\left(1-\frac{f_{s}}{x_{s}\left(\varphi, \lambda_{s}\right)}\right)
$$

Since $x_{s}\left(\varphi, \lambda_{s}\right)$ is increasing in $\lambda_{s}$ and $\varphi, \mu_{s}$ is increasing in $\lambda_{s}$ and $\varphi$ as well. The intuition is that a firm with higher product attributes and/ or firm productivity produces more and can spread the fixed cost of production (or exporting) over a larger volume of production.

Similarly, the product-specific measured productivity corresponding to sales in country $j$ is

$$
\mu_{s j}=\frac{\tau_{j} r^{\beta(s)}}{\rho}\left(1-\frac{f_{s j}}{x_{s j}\left(\varphi, \lambda_{s}\right)}\right)
$$

Notice that $\mu_{s j}>\mu_{s}$ if $\tau_{j}$ or resources allocated to production of exported goods, $x_{j}\left(\varphi, \lambda_{s}\right)$, are sufficiently high. On the other hand, higher fixed export costs, $f_{s j}$, would make $\mu_{s j}<\mu_{s}$ more likely.

The measured revenue-based productivity of an exporter (selling to country $j$ ) then becomes

$$
\widehat{T F P}_{j}(\varphi)=d_{j}(\varphi) \int_{0}^{1} \mu_{s} \frac{R_{s}\left(\varphi, \lambda_{s}\right)}{R(\varphi)} d s+\left(1-d_{j}(\varphi)\right) \int_{0}^{1} \mu_{s j} \frac{R_{s j}\left(\varphi, \lambda_{s}\right)}{R_{j}(\varphi)} d s
$$


where $d_{j}(\varphi)=\frac{R(\varphi)}{R(\varphi)+R_{j}(\varphi)}$. Denote the measured TFP before exporting by $\widehat{T F P}(\varphi)$. According to (7), when we observe $\widehat{T F P}_{j}\left(\varphi^{\prime}\right)>\widehat{T F P}(\varphi)$, it can be partly due to $\varphi^{\prime}>\varphi$, a shock that triggers exporting, and partly due to product switching and thus reallocation of resources toward the higher "consumer taste" products, conditional on $\varphi$.

In an open-economy model with symmetric countries (identical country size and factor endowment) and no iceberg trade cost, because of higher fixed costs for exporting than domestic sales, it can be readily shown that $\mu_{s j}$ is always smaller than $\mu_{s} \forall s$. In this situation, given $\varphi$, product-switching is associated with a lower measured TFP in the absence of general equilibrium effects.

However, when we consider asymmetric country size and factor endowment, the contribution of product switching becomes less clear. In particular, we can show that for a given product $s$, $\mu_{s j}>\mu_{s}$ if and only if $\tau_{j}\left(1-\frac{f_{s j}}{x_{s j}\left(\varphi, \lambda_{s}\right)}\right)>\left(1-\frac{f_{s}}{x_{s}\left(\varphi, \lambda_{s}\right)}\right)$. For simplicity, suppose $\tau_{j}=1$, this inequality is reduced to ${ }^{35}$

$$
\frac{f_{s j}}{f_{s}}<\left(\frac{P_{j}(s)}{P(s)}\right)^{\gamma} \Psi_{j}
$$

where $\Psi_{j}=\frac{R_{j} / \widehat{P}_{j}}{R / \widehat{P}}$, which is constant across $s .{ }^{36}$ Suppose $\frac{f_{s j}}{f_{s}}$ is the same for all products, since $\widetilde{P}^{\prime}(s)<0$ and $\gamma \equiv \frac{\sigma(1-\nu)-1}{(\sigma-1)(1-\nu)}>0$, the right hand side of the inequality is decreasing in $s$. That is, the inequality is less likely to hold for capital-intensive products, all else being equal. In other words, the more the exporters specialize in labor-intensive products (with relatively higher $\mu$ ), the higher the measured productivity gain is relative to the actual TFP gain, $\triangle \varphi$, after exporting. That said, it is possible that $\mu_{s j}<\mu_{s}$ even for the most labor-intensive products exported to capitalabundant countries. This would be the case if $f_{s j}$ is significantly higher than $f_{s}$, or the destination country is sufficiently small (low $R_{j}$ ) or remote (high $\widehat{P}_{j}$ ). In that case, the actual increase in TFP after exporting is always higher than the measured one. Specialization in labor-intensive exports is then associated with a relative gain, instead of an absolute gain, in measured productivity.

\section{Evidence on Heterogeneous Changes in Capital Intensity}

We have already shown robust evidence to support Proposition 1. To this end, we examine how an exporter is different in capital intensity from a non-exporter that shares very similar pre-export characteristics, which identify using the propensity-score matching techniques for Table 3. Specifi-

\footnotetext{
$35 \frac{f_{s j}}{f_{s}}<\frac{x_{j}\left(\varphi, \lambda_{s}\right)}{x\left(\varphi, \lambda_{s}\right)} \Leftrightarrow \frac{f_{s j}}{f_{s}}<\frac{r_{s j}\left(\varphi, \lambda_{s}\right)}{r_{s}\left(\varphi, \lambda_{s}\right)}=\frac{R_{s j}}{R_{s}}\left(\frac{P_{j}(s)}{P(s)}\right)^{\sigma-1}=\left(\frac{P_{j}(s)}{P(s)}\right)^{\gamma} \Psi_{j}$,

${ }^{36}$ Suppose $\tau_{j}>1, \mu_{s j}>\mu_{s}$ if and only if $\tau_{j}-1+\frac{f_{s}}{\kappa_{s}\left(\varphi, \lambda_{s}\right)}>\frac{\tau_{j} f_{s j}}{\kappa_{s j}\left(\varphi, \lambda_{s}\right)}$.
} 
cally, we estimate the following equation:

$$
\triangle \bar{\Theta}_{i}^{\text {matched }}(\varphi)-\triangle \Theta_{i}(\varphi)=\mathbf{X}_{i} \gamma+F_{\text {Ind }}+F_{\text {Prov }}+F_{\text {year }}+\varepsilon_{i}
$$

where $\triangle \Theta_{i}(\varphi)$ is the change in firm $i^{\prime}$ s capital intensity after exporting and $\triangle \bar{\Theta}_{i}^{\text {matched }}(\varphi)$ is the change in the mean capital intensity of its matched non-exporters. The main idea is to examine how an exporter is different in capital intensity from a non-exporter that shares very similar pre-export characteristics, such as ownership types. $X_{i}$ is a vector of firm $i$ 's previous year characteristics, including TFP and other key attributes. $F_{\text {Ind }}, F_{\text {Prov }}$, and $F_{\text {year }}$ stand for industry, province, and year fixed effects, respectively.

The results for estimating (9) are reported in Table 4 . In column (1), $\ln (\mathrm{TFP})$ in the previous year is negatively correlated with the gap in the change in capital intensity, suggesting a larger decline in the capital intensity of new exporters relative to the matched non-exporters. This finding supports Proposition 2. New exporter's ex ante capital intensity is associated with a larger decline in capital intensity after exporting. To the extent that more productive firm pay higher wages, the negative and significant coefficient on $\ln$ (wage rate) is also consistent with Proposition 2.

Beyond the model predictions, we also find that older firms experience a smaller decline in capital intensity after exporting. While our model assumes exogenous firm productivity and product appeal, one can argue that firms' experience in sales can enhance the level of the "consumer taste" attributes. Based on this rationale, expertise in production would imply a higher chance of selling a product in a foreign market. Finally, a positive correlation between initial capital intensity and the decline in capital intensity is consistent with our findings that more labor-intensive firms are more likely to start exporting (see Appendix Table A2). The rationale is that an ex-ante more capitalintensive firm has more room to adjust its product scope to exploit the comparative advantage of low labor costs in China, resulting in a larger drop in capital intensity. In columns (2) and (3), we find strong evidence confirming the baseline results using both the domestic and foreign firm samples.

Next, we explore the relation between the increase in labor intensity in the first year of exporting and the gain in measured productivity to shed light on the "core competency" hypothesis. According to our model predictions, new exporters that have a larger increase in labor intensity should have a larger increase in measured productivity gain, relative to non-exporters. As is shown in Table 5, we find a positive coefficient on the increase in labor intensity after exporting, controlling for industry, ownership, and year fixed effects, as well as a number of key firm attributes. This positive correlation remains robust for both domestic and foreign exporters (columns (2) and 
(3)). There results are consistent with our theoretical prediction that firms' specialization in core competency enhances measured TFP.

\section{Evidence on Within-firm Product Switching}

Since our model emphasizes the multi-product aspect of firms, in the remainder of the empirical analysis, we use transaction-level (firm-product-year) trade data to verify the theoretical results above. We first merge the NBS firm data with the trade data as discussed in Section 3. We use various methods to merge the two data sets, including merging by firm name, address, and manager names. The summary statistics of the merged data set are reported in Appendix Table A4. About one-third of the exporters in the trade data set can be merged with the NBS data set. These merged firms account for $37 \%$ to $49 \%$ (depending on the year) of the values of aggregate Chinese exports. A conservative estimate shows that over $20 \%$ of Chinese exports were intermediated by trading companies (Ahn et al., 2011; Tang and Zhang, 2012). It is worth noting that trading companies are considered service providers, which are included in the trade data but not in the NBS industrial firm data set. A large fraction of the unmerged firms in our sample are thus trading companies.

Using the merged data set, we compute capital intensity for each HS 6-digit product. The computation procedures, which are similar to the method used by Bernard et al. (2010), are discussed in Appendix A.3. Table A6 in the appendix reports the measured capital intensity by broad industries (approximately at the level of HS 2-digit). Similar to the findings by Bernard et al. (2010) for the U.S., there exists a wide variation in capital intensity within industries. For instance, the mean capital intensity of the "textiles and textile articles" industry is about 68 thousands yuan per worker, with standard deviation across HS6 products equal to about 55 thousands. The number of HS6 product categories ranges from 9 (Works of art) to 818 (Textile and textile articles), suggesting that firms have a wide range of products with vastly different capital intensity to choose from within the same industry. In fact, based on the transaction-level data, Table 6 shows that exporters actively add and drop products over time. New exporters in year $t$ (those who did not export in $t-1$ according to the NBS data set) on average added about 10 products, dropped 6 products, and continued only 5 products per year between 2002 and 2006. This active within-firm extensive margin of trade can play an important role in affecting factor intensity and measured productivity after export participation.

Using the merged data set and capital intensity measures at the HS 6-digit level, we compare the (average) capital intensity of the newly added products, dropped products, and products that were continued from the previous year. To this end, we first record all products exported in the 
first year and subsequent years for each new exporter. In each subsequent year, we keep track of the new, dropped, and continued products. Then for each exporter-year, we compute the salesweighted averages of capital intensity for each of the following product portfolios: the newly added products, the continued products, and the dropped products. With this panel data set in hand, we estimate the following specification:

$$
\ln (K / L)_{i k}=\alpha+\beta\left(\text { new_product }{ }_{i k}\right)+\delta\left(\text { dropped_product }_{i k}\right)+e_{i}
$$

where $\ln (K / L)_{i k}$ is the sales-weighted average of capital intensity for firm $i$ and basket $k \in$ $\{$ new_products,contining_products,dropped_products $\}$. $\alpha$ is a constant and $e_{i}$ the error term. Our model predicts that newly added products are less capital-intensive than the basket of continued products, while dropped products are more capital-intensive (i.e., $\beta<0$ and $\delta>0$ ).

As is shown in Table 7, the estimated coefficient on the new-product dummy is negative and significant using the pooled sample, while the dropped product dummy is positive and significant. More specifically, the new products are about 5 percent less capital-intensive than the continuously exported products, while the dropped products are about 2 percent more capital-intensive. These results continue to hold when we exclude intermediaries in column (2). Importantly, the results remain robust when we use the sample of only ordinary exporters in column (3), and only processing exporters, who assemble imported intermediates into final products solely for foreign sales, in

column (4). These findings address the concern that our results are driven by the predominance of export-processing plants in China.

Our model predicts that exporting to a more capital-abundant country should be associated with a larger decline in firm capital intensity. To examine this hypothesis, we split the sample into two, with one being a group including exporters primarily serving the capital-abundant countries and another group including exporters primarily serving the labor-abundant countries. A country is considered as capital-abundant if has relative capital endowment than the median in our sample. We then run the same regression over the two different samples. As is shown in columns (5) and (6), products added by exporters serving capital-abundant destinations tend to be less capital-intensive, compared to those added by exporters serving labor-abundant destinations. There is little difference in the factor intensity of the dropped products between the two groups of exporters.

\section{Concluding Remarks}

This paper analyzes the causal relations between firms' productivity, factor intensity, and export participation. In particular, we provide empirical evidence on how firms' specialization in core 
products after exporting can affect their factor intensity and measured productivity. Using panel data for China's manufacturing firms over the period of 1998-2007 and the matched sampling techniques for identification, we find that exporting increases domestic firms' measured productivity but lowers their capital intensity.

To rationalize these results that contrast sharply to the existing literature, we develop a variant of the model by Bernard, Redding, and Schott $(2010,2011)$ to consider firms producing multiple products with varying capital intensity. Our model predicts that firms in labor-abundant countries specialize in their core competencies by allocating more resources to produce labor-intensive products once they start exporting. We discuss how this within-firm reallocation of resources account for higher measured productivity after exporting. Firm ex ante productivity is associated with a smaller decline in capital intensity after exporting. A sharper post-exporting decline in capital intensity is associated with a larger increase in measured total factor productivity. Using transaction-level trade data, we find evidence that Chinese exporters add new products that are more labor-intensive than the existing exported products, and drop products that are less laborintensive over time. 


\section{References}

1. Ahn, J., A. Khandelwal, and S.J. Wei (2011) The Role of Intermediaries in Facilitating Trade, Journal of International Economics, 84, 73-85.

2. Alvarez, R., and R. Lopez (2005) Exporting and Performance: Evidence from Chilean Plants, Canadian Journal of Economics, 38, 1384-1400.

3. Arkolakis, C. and M. Muendler (2011) The Extensive Margin of Exporting Products: A Firm-Level Analysis, Yale University, working paper.

4. Aw, B., S. Chung, and M. Roberts (2000) Productivity and Turnover in the Export Market: Micro-level Evidence from the Republic of Korea and Taiwan (China), World Bank Economic Review, 14, 65-90.

5. Aw, B., M. Roberts, D. Xu (2011) R\&D Investment,Exporting, and Productivity Dynamics, American Economic Review, 101, 1312-1344.

6. Baldwin J. and W. Gu (2003) Export-market participation and productivity performance in Canadian manufacturing, Canadian Journal of Economics, 36, 634-657.

7. Becker, S. and A. Ichino (2002) Estimation of average treatment effects based on propensity scores, Stata Journal.

8. Bernard, A., J. Eaton, B. Jensen, and S. Kortum (2003) Plants and Productivity in International Trade, American Economic Review, 93, 1268-1290.

9. Bernard, A., and J. Jensen (1997) Exporters, Skill Upgrading, and the Wage Gap, Journal of International Economics, 42, 3-31.

10. Bernard, A., and B. Jensen (1999) Exceptional Exporter Performance: Cause, Effect, or Both?, Journal of International Economics, 47, 1-25.

11. Bernard, A., and J. Jensen (2004) Why Some Firms Export, Review of Economics and Statistics, 86, 561-568.

12. Bernard A., J. Jensen, S. Redding, and P.K. Schott, (2007) Firms in International Trade, Journal of Economic Perspectives, 21, 105-130.

13. Bernard, A., J. Jensen, and P. K. Schott (2006) Survival of the Best Fit: Exposure to Low Wage Countries and The (Uneven) Growth of US Manufacturing Plants, Journal of International Economics, 68, 219-237. 
14. Bernard, A. B., S. Redding, and P. K. Schott (2007) Comparative Advantage and Heterogeneous Firms, Review of Economic Studies, 74, 31-66.

15. Bernard, A., S. Redding, and P. Schott (2010) Multiple-Product Firms and Product Switching, American Economic Review, 100, 70-97.

16. Bernard, A., S. Redding, and P. Schott (2011) Multi-Product Firms and Trade Liberalization, Quarterly Journal of Economics, 126, 1271-1318.

17. Bernard, A., and J. Wagner (1997) Exports and Success in German Manufacturing, Weltwirtschaftliches Archiv, 133, 134-157.

18. Brandt, L., J. Van Biesebroeck, and Y. Zhang (2011) Creative Accounting or Creative Destruction? Firm-level Productivity Growth in Chinese Manufacturing, Journal of Development Economics, forthcoming.

19. Bastos, P. and Joana, S. (2010) The quality of a firm's exports: Where you export to matters, Journal of International Economics, 82(2), 99-111.

20. Bustos, P. (2011) Trade Liberalization, Exports, and Technology Upgrading: Evidence on the Impact of MERCOSUR on Argentinian Firms, American Economic Review, 101, 304-340.

21. Clerides, S., S. Lach, and J. Tybout (1998) Is Learning by Exporting Important? Microdynamic Evidence from Colombia Mexico, and Morocco, Quarterly Journal of Economics, 113, 903-947.

22. De Loecker, J. (2007) Do Exports Generate Higher Productivity? Evidence from Slovenia, Journal of International Economics, 73, 69-98.

23. Delgado, M., J. Farinas, and S. Ruano (2002) Firm Productivity and Export Markets: A Nonparametric Approach, Journal of International Economics, 57, 397-422.

24. Eckel, C., and J.P. Neary (2010) Multi-product Firms and Flexible Manufacturing in the Global Economy, Review of Economic Studies, 77, 188-217.

25. Fan, J. (1993) Local Linear Regression Smoothers and their Minimax Efficiencies, Annals of Statistics, 21, 196-216.

26. Feenstra, R. and H. Ma (2008) Optimal Choice of Product Scope for Multiproduct Firms under Monopolistic Competition, in E. Helpman, D. Marin and T. Verdier, eds., The Organization of Firms in a Global Economy, Harvard University Press. 
27. Feenstra R. and G. Hanson (2005), "Ownership and Control in Outsourcing to China: Estimating the Property-Rights Theory of the Firm," Quarterly Journal of Economics 120, 729-761.

28. Gibbons, J. D., and S. Chakraborti (2003) Nonparametric Statistical Inference, New York: Marcel Dekker.

29. Girma, S., D. Greenaway, and R. Kneller (2003) Export Markets Exit and Performance Dynamics: A Causality Analysis of Matched Firms, Economics Letters, 80, 181-187.

30. Harrigan, J. and Reshef, A. (2012) Skill Biased Heterogeneous Firms, Trade Liberalization and the Skill Premium, University of Virginia, working paper.

31. Heckman, J., H. Ichimura, and P. Todd (1997) Matching as an Econometric Evaluation Estimator, Review of Economic Studies, 65, 261-294.

32. Helpman, E., M. Melitz, and S. Yeaple (2004) Export vs. FDI with Heterogeneous Firms, American Economic Review, 94, 300-316.

33. Hsieh, C. T., and Klenow, P. J. (2009). Misallocation and manufacturing TFP in China and India. Quarterly Journal of Economics, 124(4), 1403-1448.

34. International Study Group on Exports and Productivity (2008) Exports and Productivity Comparable Evidence for 14 Countries, Review of World Economics, 144, 636-659.

35. Iacovone, L. and B. Javorcik (2012) Getting Ready: Preparation for Exporting, University of Oxford, mimeo.

36. Jefferson, G, T. Rawski, and Y. Zhang (2008) Productivity Growth and Convergence across China's Industrial Economy, Journal of Chinese Economic and Business Studies, 6, 120-141.

37. Konings, J. and H. Vandenbussche (2005), Heterogeneous responses of firms to trade protection, Journal of International Economics, 76, 371-383.

38. Kraay, A. (1999) Exports and Economic Performance: Evidence from a Panel of Chinese Enterprises, Revue d'Economie du Development, 1-2, 183-207.

39. Leuven, E., and B. Sianesi (2003) PSMATCH2: Stata Module to Perform Full Mahalanobis and Propensity Score Matching, Common Support Graphing, and Covariate Imbalance Testing, http://ideas.repec.org/c/boc/bocode/s432001.html. 
40. Lucas, R. (1978) On the Size Distribution of Business Firms, Bell Journal of Economics, 9, 508-523.

41. Levinsohn, J., and A. Petrin (2003) Estimating Production Functions Using Inputs to Control for Unobservables, Review of Economics Studies, 70, 317- 342.

42. Lileeva, A., and D. Trefler (2010) Improved Access to Foreign Markets Raises Plant-Level Productivity... for Some Plants, Quarterly Journal of Economics,125, 1051-1099

43. Lu, D. (2010) Exceptional Exporter Performance? Evidence from Chinese Manufacturing Firms, Working Paper, University of Chicago.

44. Dai, M., M. Maitra, and M. Yu (2011) Unexceptional Exporter Performance in China? Role of Processing Trade, Peking University working paper.

45. Jefferson, G., T. Rawski, and Y. Zhang (2008) Productivity Growth and Convergence across China's Industrial Economy, Journal of Chinese Economic and Business Studies, 6(2), 120141.

46. Manova, K. and Z. Zhang (2012) Export Prices across Firms and Destinations, Quarterly Journal of Economics 127, 379-436.

47. Mayer, T., M. Melitz, G. Ottaviano (2012) Market Size, Competition, and the Product Mix of Exporters, Harvard University, working paper.

48. Melitz, M. (2003) The Impact of Trade on Intra-industry Reallocations and Aggregate Industry Productivity, Econometrica, 71, 1695-1725.

49. Nocke, V. and S. Yeaple (2008) Globalization and the Size Distribution of Multiproduct Firms, NBER Working Paper, No. 12322.

50. Park, A., D. Yang, X. Shi, and Y. Jiang (2007) Exporting and Firm Performance: Chinese Exporters and the Asian Financial Crisis, working paper, University of Michigan.

51. Perkins, D.H.,and T.G. Rawski (2008) Forecasting China's Economic Growth. In Brandt, L., and T.G. Rawski (Eds.), China's Great Economic Transformation, Cambridge University Press.

52. Petrin, A., B. Poi, and J. Levinsohn (2004) Production Function Estimation in Stata Using Inputs to Control for Unobservables, Stata Journal, 4, 113-123. 
53. Rosenbaum, P.R., and D.B. Rubin (1984) Reducing Bias in Observational Studies using Subclassification on the Propensity Score, Journal of the American Statistical Association, $79,516-524$.

54. Tang, H., and Y. Zhang (2012) Quality Differentiation and Trade Intermediation, Tufts University Working Paper.

55. Van Biesebroeck, J. (2005) Exporting Raises Productivity in sub-Saharan African Manufacturing Firms, Journal of International Economics, 67, 373-391.

56. Verhogeen, E. (2008) Trade, Quality Upgrading and Wage Inequality in the Mexican Manufacturing Sector, Quarterly Journal of Economics, vol 123, pp. 489-530.

57. Wagner, J. (2002) The Causal Effect of Exports on Firm Size and Labor Productivity: First Evidence from a Matching Approach, Economics Letters, 77, 287-292.

58. World Bank (1993) The East Asian Miracle: Economic Growth and Public Policy, New York: Oxford University Press.

59. Yeaple, S. (2005) A Simple Model of Firm Heterogeneity, International Trade, and Wages, Journal of International Economics, 65, 1-20. 


\section{A Appendix (not for publication)}

\section{A.1 Difference-in-difference (DID) Matching Estimator}

This appendix discusses the difference-in-difference $(D I D)$ matching estimator of Heckman, Ichimura, and Todd (1997). We need to estimate the average effect of exporting on the export starters in a given year as follows:

$$
E\left[S_{i}^{1}-S_{i}^{0} \mid \text { Start }_{i}=1\right]=E\left[S_{i}^{1} \mid \text { Start }_{i}=1\right]-E\left[S_{i}^{0} \mid \text { Start }_{i}=1\right],
$$

where the superscript denotes the export status. The challenge is that the counterfactual outcome if the exporter did not export, $S_{i}^{0}$, is not observable. The DID matching estimator is a non-parametric approach to estimating the effect of exporting $\left(D I D_{X}\right)$ in year $t$, which is given by the following formula:

$$
D I D_{X, t}=\frac{1}{n_{1}} \sum_{i \in I_{1} \cap C_{p}}\left[\left(S_{1, t, i}-S_{0, t-1, i}\right)-\sum_{j \in I_{0} \cap C_{p}} W(i, j)\left(S_{0, t, i}-S_{0, t-1, i}\right)\right]
$$

where $S_{1, t, i}$ is firm $i$ 's characteristics, including TFP and capital intensity (K/L). Subscript ' 1 ,t' denotes firms that start exporting in year $t$, which are not exporting at year $t-1$ and therefore are denoted by subscript ' $0, t-1$ '. Subscript ' $0, t$ ' denotes firms that never export in the sample period. $I_{1}$ denotes the group of new exporters. $C_{p}$ is the region of common support. $n_{1}$ is the number of new exporters that can be matched by a corresponding comparison group. $W(i, j)$ is the non-parametric weight from the local linear regression on propensity score, defined as

$$
W(i, j)=\frac{G_{i j} \sum_{k \in I_{0}} G_{i k}\left(P_{k}-P_{i}\right)^{2}-G_{i j}\left(P_{j}-P_{i}\right) \sum_{k \in I_{0}} G_{i k}\left(P_{k}-P_{i}\right)}{\sum_{j \in I_{0}} G_{i j} \sum_{k \in I_{0}} G_{i k}\left(P_{k}-P_{i}\right)^{2}-\left[\sum_{k \in I_{0}} G_{i k}\left(P_{k}-P_{i}\right)\right]^{2}}
$$

where $G_{i j}=G\left(\left(P_{i}-P_{j}\right) / h_{n}\right), G($.$) and h_{n}$ denote a kernel function and a bandwidth parameter respectively. $P_{i}$ is the propensity score of firm i estimated by a probit model conditional on a vector of pre-entry characteristics of firms including $\ln (\mathrm{TFP})$, wage, capital intensity, firm age, sales, and province fixed effects.

The propensity score matching is implemented by the PSMATCH2 module in Stata developed by Leuven and Sianesi (2003). Technical details about the local linear regression matching estimator and the nearest neighbor matching estimator can be found in Fan (1993) and Becker and Ichino (2002).

\section{A.2 Theoretical Derivation}

We first present the derivation of the consumer taste cutoffs for domestic sales, $\lambda_{s}^{*}(\varphi)$, and exports, $\lambda_{s j}^{*}(\varphi)$, which are omitted in the main text. For a firm with total factor productivity $\varphi$, the consumer taste cutoff $\lambda_{s}^{*}(\varphi)$ for product $s$, above which the firm produces the product for domestic sales, can be obtained by solving the following zero-profit condition (see BRS (2010) for details):

$$
\pi_{s}\left(\varphi, \lambda_{s}^{*}(\varphi)\right)=\frac{R_{s}}{\sigma}\left(\rho P(s) \varphi \lambda_{s}^{*}(\varphi)\right)^{\sigma-1}-f_{s} r^{\beta(s)}=0,
$$

where $\pi_{s}\left(\varphi, \lambda_{s}^{*}(\varphi)\right)$ represents the firm's profit by selling a variety of product $i$ domestically; $R_{s}$ stands for domestic expenditure spent on product $s . P(s)$ is the ideal price index for product $s$. Specifically, consumers' utility maximization yields $R_{s}=\left[P(s)^{\frac{-\nu}{1-\nu}} / \int_{0}^{1} P(k)^{\frac{-\nu}{1-\nu}} d k\right] R$, where $R$ 
is total expenditure of the economy; $P(s)=\left[\int_{\omega \in \Omega_{s}} p(s, \omega)^{1-\sigma} d \omega\right]^{\frac{1}{1-\sigma}}$. Expressing $R_{s}$ in terms of $P(s), R$, and $\widehat{P}=\int_{0}^{1} P(k)^{\frac{-\nu}{1-\nu}} d k$ in (A-1) gives the following expression.

$$
\lambda_{s}^{*}(\varphi)=\frac{\varsigma P(s)^{-\gamma}}{\varphi}\left(\frac{r^{\beta(s)} f_{s} \widehat{P}}{R}\right)^{\frac{1}{\sigma-1}}
$$

where $\varsigma=\frac{\sigma^{\frac{1}{\sigma-1}}}{\rho}$ and $\gamma=\frac{\sigma(1-\nu)-1}{(\sigma-1)(1-\nu)} \cdot \gamma>0$ if $1<\sigma(1-\nu)$. Similarly, we can use the zero-profit condition for export sales of product $s$ to country $j$ to solve for the consumer taste cutoff for foreign sales as

$$
\lambda_{s j}^{*}(\varphi)=\frac{\varsigma \tau_{j} P_{j}(s)^{-\gamma}}{\varphi}\left(\frac{r^{\beta(s)} f_{s j} \widehat{P}_{j}}{R_{j}}\right)^{\frac{1}{\sigma-1}} .
$$

Dividing $\lambda_{s j}^{*}(\varphi)$ by $\lambda_{s}^{*}(\varphi)$ gives the ratio in (4).

Next, we show that $\frac{P_{j}(s)}{P(s)}$ is decreasing in $s$ if $j$ is more capital-abundant than China (i.e., $\frac{w_{j}}{r_{j}}>\frac{1}{r}$ ). The price indices for a given product (suppressed product index $s$ for simplicity) in China $(c)$ and in country $j$, respectively are

$$
\begin{aligned}
& P_{j}=\left[\int_{\omega \in \Omega j}\left(\frac{p_{j}(\omega)}{\lambda_{j}(\omega)}\right)^{1-\sigma} d \omega+\int_{\omega \in \Omega_{c j}}\left(\frac{\tau_{c j} p_{c}(\omega)}{\lambda(\omega)}\right)^{1-\sigma} d \omega\right]^{\frac{1}{1-\sigma}} ; \\
& P_{c}=\left[\int_{\omega \in \Omega_{c}}\left(\frac{p_{c}(\omega)}{\lambda(\omega)}\right)^{1-\sigma} d \omega+\int_{\omega \in \Omega_{j c}}\left(\frac{\tau_{j c} p_{j}(\omega)}{\lambda(\omega)}\right)^{1-\sigma} d \omega\right]^{\frac{1}{1-\sigma}},
\end{aligned}
$$

where $\Omega_{k}$ represents the set of products sold by firms in the domestic market $k$, and $\Omega_{k l}$ stands for the set of products exported by domestic firms in country $k$ to country $l$. $\tau_{k l}>1$ is the iceberg trade cost for exporting from country $k$ to country $l$.

Following the procedures in Bernard et al. (2007), the two price indices can be expressed as

$$
\begin{aligned}
& P_{j}=\left[M_{j}\left(\frac{w_{j}^{1-\beta} r_{j}^{\beta}}{\rho \widetilde{\varphi}_{j}}\right)^{1-\sigma}+M_{c j}\left(\frac{\tau_{c j} r^{\beta}}{\rho \widetilde{\varphi}_{c j}}\right)^{1-\sigma}\right]^{\frac{1}{1-\sigma}} ; \\
& P_{c}=\left[M_{c}\left(\frac{r^{\beta}}{\rho \widetilde{\varphi}_{c}}\right)^{1-\sigma}+M_{j c}\left(\frac{\tau_{j c} w_{j}^{1-\beta} r_{j}^{\beta}}{\rho \widetilde{\varphi}_{j c}}\right)^{1-\sigma}\right]^{\frac{1}{1-\sigma}},
\end{aligned}
$$

where $\widetilde{\varphi}_{k}$ represents the weighted average productivity of firms selling in the domestic market $k$, weighted by the product attributes $\lambda$ (see Bernard et al. (forthcoming) for details); while $\widetilde{\varphi}_{k l}$ represents the weighted average productivity of firms in country $k$ that export to country $l$. $M_{k}$ and $M_{k l}$ are the mass of firms selling in own market $k$ or exporting from country $k$ to country $l$, respectively.

All these variables can be solved in general equilibrium in terms of underlying parameters of the distribution of $\varphi$ and $\lambda$, given a constant mass of potential entrants. To conserve space, we refer the readers to Bernard et al. (2007 and 2010) for details. For simplicity, assume that each country has a mass of $M$ potential entrants at any given point in time. Without solving the model fully, we 
do know that since the fixed cost for exporting is higher than that for domestic sales, $M_{c}>M_{c j}$, $M_{j}>M_{j c}, \widetilde{\varphi}_{c j}>\widetilde{\varphi}_{c}$, and $\widetilde{\varphi}_{j c}>\widetilde{\varphi}_{j}$. Let us also assume that $M_{j} / M_{c}, M_{j c} / M_{c j}$, and $\widetilde{\varphi}_{c} / \widetilde{\varphi}_{j}$ are all increasing in $\beta$. We will come back to verify the validity of these assumptions later.

$$
\left(\frac{P_{j}}{P_{c}}\right)^{\sigma-1}=\frac{\frac{M_{c}}{M_{j}}+\frac{M_{j c}}{M_{j}}\left(\frac{\widetilde{\varphi}_{j c}}{\widetilde{\varphi}_{c}} \frac{1}{\tau_{j c} w_{j}}\left(\frac{w_{j} r}{r_{j}}\right)^{\beta}\right)^{\sigma-1}}{\left(\frac{\widetilde{\varphi}_{j}}{\widetilde{\varphi}_{c}} \frac{1}{w_{j}}\left(\frac{w_{j} r}{r_{j}}\right)^{\beta}\right)^{\sigma-1}+\frac{M_{c j}}{M_{j}}\left(\frac{\widetilde{\varphi}_{c j}}{\tau_{c j} \widetilde{\varphi}_{c}}\right)^{\sigma-1}} .
$$

Since $\frac{w_{j}}{r_{j}}>\frac{w}{r} \Longrightarrow \frac{w_{j} r}{r_{j}}>1$. With the assumptions on $M^{\prime}$ 's and $\widetilde{\varphi}^{\prime} s$ we made, it can be readily shown that $\left(\frac{P_{j}}{P_{c}}\right)^{\sigma-1}$ is decreasing in $\beta$ (capital intensity). Thus, given a relatively "tougher market" for capital-intensive sectors in $j$, and given the mass of firms $M$, we can then show that $M_{j} / M_{c}, M_{j c} / M_{c j}$, and $\widetilde{\varphi}_{c} / \widetilde{\varphi}_{j}$ are all increasing in $\beta$, confirming our initial assumptions.

\section{A.2.1 Discussion about Proposition 1}

We now discuss briefly the argument that Proposition 1 holds as long as $\exists \bar{s}(\varphi) \in(0,1]$ such that $\lambda_{s j}^{*}(\varphi) \leq \lambda_{s}^{*}(\varphi) \forall s \leq \bar{s}(\varphi)$ and $\lambda_{s j}^{*}(\varphi)>\lambda_{s}^{*}(\varphi) \forall s>\bar{s}(\varphi)$. That is, for some products, there always exist customer taste cutoffs for exporting that are higher than those for domestic sales. Consider a firm that receives a favorable productivity shock (i.e., $\varphi_{t}>\varphi_{t-1}$ ) that triggers exporting to country $j$. Consider a given set of "consumer tastes", $\lambda^{\prime} s$. For $s \leq \bar{s}(\varphi)$, the probability that the firm exports product $s$ to country $j$, conditional on positive domestic sales of product $s$ is equal to $\Pi_{1}=1$. For $s \leq \bar{s}(\varphi)$, the probability of positive export sales conditional on no domestic sales is $\Pi_{2}=\frac{1-G\left(\lambda_{s j}^{*}(\varphi)\right)}{G\left(\lambda_{s}^{*}(\varphi)\right)}$. For $s>\bar{s}(\varphi)$, the probability of positive export sales conditional on positive domestic sales (the standard consideration) is $\Pi_{3}=\frac{1-G\left(\lambda_{s j}^{*}(\varphi)\right)}{1-G\left(\lambda_{s}^{*}(\varphi)\right)}$; and the probability of positive export sales conditional on no domestic sales is $\Pi_{4}=0$. $\Pi_{2}$ is increasing in $s$ while $\Pi_{3}$ is decreasing in $s$ if and only if $\lambda_{s j}^{*}(\varphi) / \lambda_{s}^{*}(\varphi)$ is increasing in $s$. Considering all four situations together, a new exporter is more likely to add products if $s \leq \bar{s}(\varphi)$; but less likely to export products with $s>\bar{s}(\varphi)$, less so for higher $s$. This mechanism delivers $\Theta_{d}(\varphi)>\Theta_{j}(\varphi)$. In sum, Proposition 1 still holds even $\lambda_{s j}^{*}(\varphi) \leq \lambda_{s}^{*}(\varphi) \forall s \leq \bar{s}(\varphi) \in(0,1]$.

\section{A.2.2 Proof of Corollary 1}

The expression for the capital intensity of the firm after exporting (eq. (6)) can be rewritten as follows:

$\Theta_{d+j}(\varphi)=\int_{0}^{1}\left\{\theta_{s} \int_{\lambda_{s}^{*}(\varphi)}^{\Phi_{j}(s) \lambda_{s}^{*}(\varphi)} \widehat{R}_{s}\left(\varphi, \lambda_{s}\right) g\left(\lambda_{s}\right) d \lambda_{s}+\int_{\Phi_{j}(s) \lambda_{s}^{*}(\varphi)}^{\infty}\left[\widehat{R}_{s}\left(\varphi, \lambda_{s}\right)+\widehat{R}_{s j}\left(\varphi, \lambda_{s}\right)\right] g\left(\lambda_{s}\right) d \lambda_{s}\right\} d s$,

where $\widehat{R}_{s}\left(\varphi, \lambda_{s}\right) \equiv \frac{R_{s}\left(\varphi, \lambda_{s}\right)}{R(\varphi)+R_{j}(\varphi)}$ and $\widehat{R}_{s j}\left(\varphi, \lambda_{s}\right) \equiv \frac{R_{s j}\left(\varphi, \lambda_{s}\right)}{R(\varphi)+R_{j}(\varphi)}$. Notice that for products that have $\lambda_{s} \in\left[\lambda_{s}^{*}(\varphi), \Phi_{j}(s) \lambda_{s}^{*}(\varphi)\right)$, the firm only sells the product in the domestic market, making revenue equal to $R_{s}\left(\varphi, \lambda_{s}\right)$ as before. Their shares in the firm's total sales will drop (i.e., $\frac{R_{s}\left(\varphi, \lambda_{s}\right)}{R(\varphi)+R_{j}(\varphi)}<$ $\left.\frac{R_{s}\left(\varphi, \lambda_{s}\right)}{R(\varphi)}\right)$. For products that have $\lambda_{s}^{*}(\varphi)>\Phi_{j}(s) \lambda_{s}^{*}(\varphi)$, the change in the share of each individual product is ambiguous. However, since products with $\lambda_{s}^{*}(\varphi)<\Phi_{j}(s) \lambda_{s}^{*}(\varphi)$ all have lower shares in the firm's total sales, at least some products with $\lambda_{s}^{*}(\varphi)>\Phi_{j}(s) \lambda_{s}^{*}(\varphi)$ must experience an 
increase in their share in the firm's total sales, contributing a larger weight in affecting the firm's capital intensity. Since $\frac{\partial \Phi_{j}(s)}{\partial s}>0$, the probability that the product will have a larger weight is decreasing in $s$. In other words, labor-intensive products are more likely to have a larger weight in the firm's product portfolio. By the law of large number, the firm's capital intensity will be lower after exporting to a country that is more capital-abundant than China.

Now consider another firm that has the same $\varphi$. By the law of large number, its ex ante average capital intensity across products is the same, yielding the same ex ante firm capital intensity. Suppose it also starts exporting but to country $k$, which is less capital-abundant than $j$ but more capital abundant than China. For simplicity, suppose all costs for exporting to $k$ are the same as those for exporting to $j\left(\tau_{j}=\tau_{k}, f_{s j}=f_{s k}\right)$, and that both destination countries have the same real incomes, $\frac{\Phi_{k}(s)}{\Phi_{j}(s)}$ can be expressed as follows: ${ }^{37}$

$$
\frac{\Phi_{k}(s)}{\Phi_{j}(s)}=\left(\frac{P_{j}(s)}{P_{k}(s)}\right)^{\gamma}
$$

Given that $k$ is more capital-abundant than $j, \frac{P_{j}(s)}{P_{k}(s)}$ and thus $\frac{\Phi_{k}(s)}{\Phi_{j}(s)}$ are increasing in $s .{ }^{38}$ In words, if the destination country is more capital-abundant, the product cutoff for exporting is rising faster in $s$. Thus, destination countries' capital endowment will be associated with different product composition and thus firm capital intensity. If $\Phi_{k}(s) / \Phi_{j}(s)$ is increasing in $s$ and $\Phi_{k}(s)>\Phi_{j}(s)$ for $s>\widehat{s} \in(0,1)$, according to eq. (A-2), by the law of large number, exporting to a more capitalabundant country is associated with larger shares of labor-intensive products in the firm's product portfolio. Thus, $\Theta_{d+k}(\varphi)<\Theta_{d+j}(\varphi)$ even though the two firms have the same ex ante capital intensity.

\section{A.3 Procedures to compute the measures of capital intensity at the HS 6-digit level}

\section{A.3.1 Use the pooled sample}

1. Calculate the capital intensity of each firm in the National Bureau of Statistics (NBS) firm data.

2. Merge NBS data with customs data using firm names, addresses, and other firm identifiers.

3. For each HS6 product, calculate the weighted average of capital intensity, with weights equal to firm sales of the same product according to the NBS data set.

\section{A.3.2 For each new exporter}

1. For new exporters in 2001 (who didn't export in 2000, the first year in the customs data set), find continuing products and newly added products in 2002.

2. For each new exporter in 2001, calculate the capital intensity of new products and continuing products in 2002 .

3. Repeat the Steps 1-2 for 2002 all the way to 2005.

\footnotetext{
${ }^{37}$ Generically, $\frac{\Phi_{k}(s)}{\Phi_{k}(s)}=\frac{\tau_{k}}{\tau_{j}}\left(\frac{f_{s k}}{f_{s j}} \frac{R_{j} / \widehat{P}_{j}}{R_{k} / \widehat{P}_{k}}\right)^{\frac{1}{\sigma-1}}\left(\frac{P_{j}(s)}{P_{k}(s)}\right)^{\gamma}$.

${ }^{38}$ For our assumption of identical price indices across countries (i.e., $\widehat{P}_{j}=\widehat{P}_{k}$ ) to hold and $\frac{\partial \frac{P_{j}(s)}{P_{k}(s)}}{\partial s}>0$, there must exist $\widehat{s} \in(0,1)$ so that $P_{j}(s)<P_{k}(s)$ for $s \in(0, \widehat{s})$ and $P_{j}(s) \geq P_{k}(s)$ for $s \in[\widehat{s}, 1)$.
} 
Figure 1: Ten-year Unbalanced Sample, Average In(K/L)

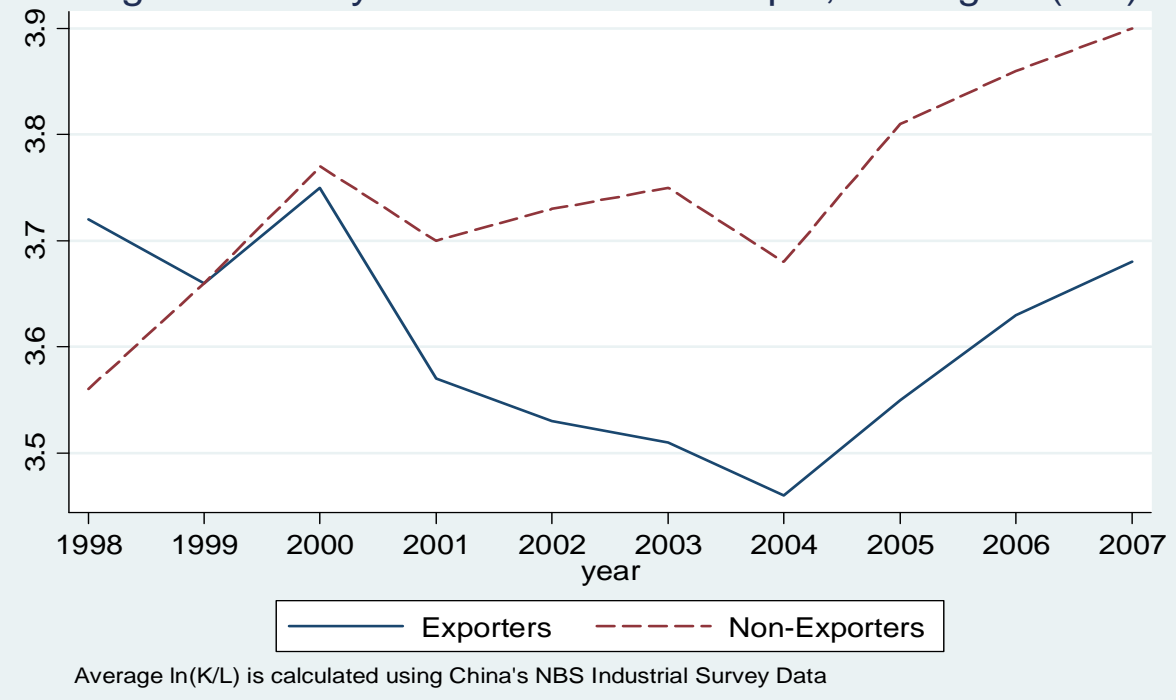

Figure 2: Ten-year Balanced Sample, Average In(K/L)

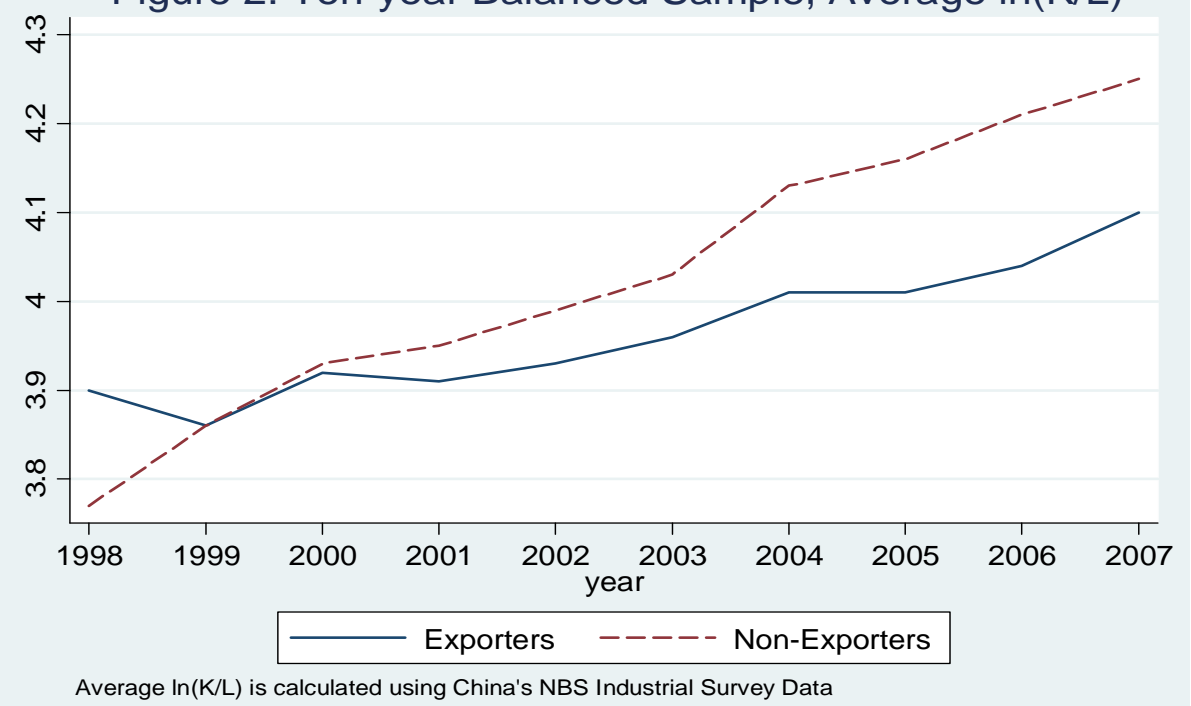

Figure 3: Distribution of $\ln (K / L))$ in 2007

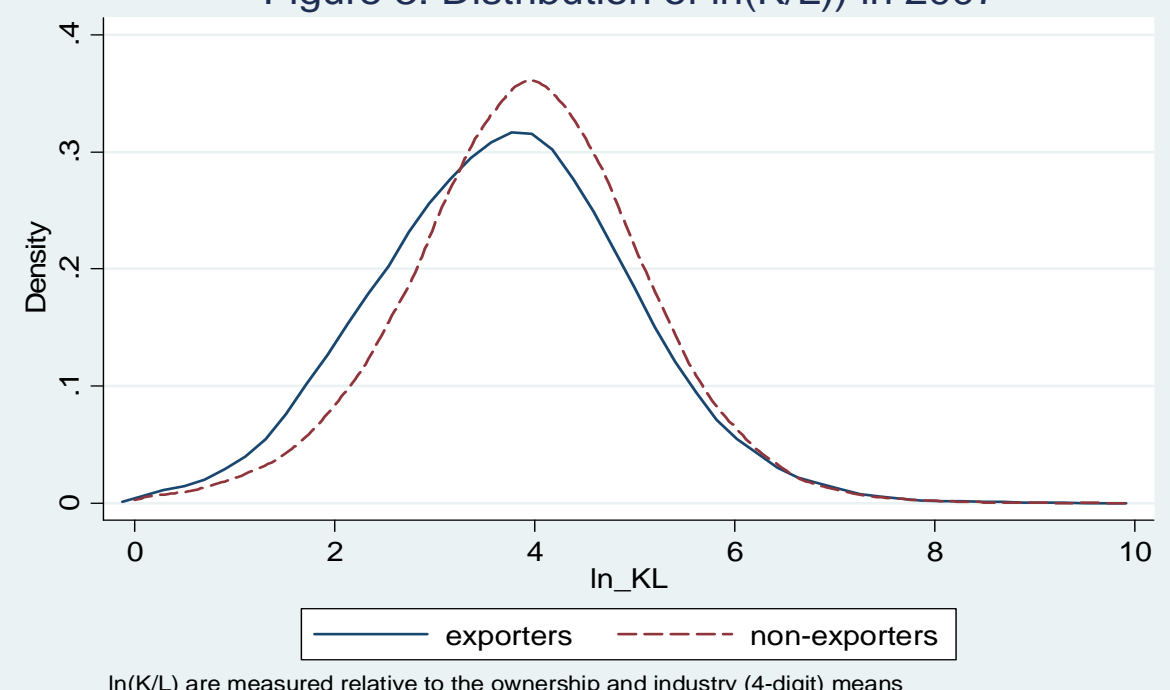

$\ln (\mathrm{K} / \mathrm{L})$ are measured relative to the ownership and industry (4-digit) means 
Table 1: Comparing Productivity and Capital Intensity of Exporters and Non-Exporters

\begin{tabular}{|c|c|c|c|c|c|c|c|}
\hline & (1) & $(2)$ & (3) & (4) & $(5)$ & $(6)$ & (7) \\
\hline & All Firms & All Firms & All Firms & $\begin{array}{l}\text { Domestic } \\
\text { Firms }\end{array}$ & $\begin{array}{l}\text { Foreign } \\
\text { Firms }\end{array}$ & $\begin{array}{c}\text { Before } \\
\text { WTO }\end{array}$ & $\begin{array}{l}\text { After } \\
\text { WTO }\end{array}$ \\
\hline \multicolumn{8}{|c|}{ Panel A: Dependent variable In(TFP) } \\
\hline Exporter & $\begin{array}{c}0.137 \\
{[0.000]^{* * *}}\end{array}$ & $\begin{array}{c}0.087 \\
{[0.000]^{* * *}}\end{array}$ & $\begin{array}{c}0.124 \\
{[0.000]^{* * *}}\end{array}$ & $\begin{array}{c}0.095 \\
{[0.001]^{* * *}}\end{array}$ & $\begin{array}{c}0.003 \\
{[0.439]}\end{array}$ & $\begin{array}{c}0.132 \\
{[0.000]^{* * *}}\end{array}$ & $\begin{array}{c}0.074 \\
{[0.000]^{* * *}}\end{array}$ \\
\hline $\mathrm{N}$ & $1,916,347$ & $1,916,347$ & $1,916,347$ & $1,495,115$ & 421,232 & 543,921 & $1,372,426$ \\
\hline \multicolumn{8}{|c|}{ Panel B: Dependent variable $\ln (\mathrm{K} / \mathrm{L})$} \\
\hline Exporter & $\begin{array}{c}-0.191 \\
{[0.000]^{* * *}}\end{array}$ & $\begin{array}{c}-0.062 \\
{[0.000]^{* * *}}\end{array}$ & $\begin{array}{c}-0.054 \\
{[0.000]^{* * *}}\end{array}$ & $\begin{array}{c}-0.072 \\
{[0.000]^{* * *}}\end{array}$ & $\begin{array}{c}-0.031 \\
{[0.000]^{* * *}}\end{array}$ & $\begin{array}{c}-0.021 \\
{[0.000]^{* * *}}\end{array}$ & $\begin{array}{c}-0.075 \\
{[0.000]^{* * *}}\end{array}$ \\
\hline $\mathrm{N}$ & $1,976,637$ & $1,976,637$ & $1,976,637$ & $1,555,076$ & 421,561 & 568,127 & $1,431,350$ \\
\hline \multicolumn{8}{|c|}{ Panel C: Dependent variable $\ln (K / L)$, alternative measure of $K$} \\
\hline Exporter & $\begin{array}{c}-0.171 \\
{[0.000]^{* * *}}\end{array}$ & $\begin{array}{c}-0.024 \\
{[0.000]^{* * *}}\end{array}$ & $\begin{array}{c}-0.028 \\
{[0.000]^{* * *}}\end{array}$ & $\begin{array}{c}-0.026 \\
{[0.000]^{* * *}}\end{array}$ & $\begin{array}{c}-0.017 \\
{[0.078]^{*}}\end{array}$ & $\begin{array}{c}0.002 \\
{[0.564]}\end{array}$ & $\begin{array}{c}-0.025 \\
{[0.000]^{* * *}}\end{array}$ \\
\hline $\mathrm{N}$ & $1,982,457$ & $1,982,457$ & $1,982,457$ & $1,560,779$ & 421,678 & 568,725 & $1,413,365$ \\
\hline \multicolumn{8}{|c|}{ Panel D: Dependent variable $\ln (K / L)$, alternative measure of $L$} \\
\hline Exporter & $\begin{array}{c}-0.311 \\
{[0.000]^{* * *}}\end{array}$ & $\begin{array}{c}-0.143 \\
{[0.000]^{* * *}}\end{array}$ & $\begin{array}{c}-0.116 \\
{[0.000]^{* * *}}\end{array}$ & $\begin{array}{c}-0.175 \\
{[0.000]^{* * *}}\end{array}$ & $\begin{array}{c}-0.078 \\
{[0.000]^{* * *}}\end{array}$ & $\begin{array}{c}-0.124 \\
{[0.000]^{* * *}}\end{array}$ & $\begin{array}{c}-0.158 \\
{[0.000]^{* * *}}\end{array}$ \\
\hline $\mathrm{N}$ & $1,976,637$ & $1,976,637$ & $1,976,637$ & $1,554,766$ & 421,463 & 568,121 & $1,431,480$ \\
\hline Year FE & Yes & Yes & No & Yes & Yes & Yes & Yes \\
\hline Industry (4-digit) FE & No & Yes & No & Yes & Yes & Yes & Yes \\
\hline Ownership FE & No & Yes & No & No & No & Yes & Yes \\
\hline Firm FE & No & No & Yes & No & No & No & No \\
\hline
\end{tabular}

Notes: This table reports estimation results for equation (1) in the text. The Exporter dummy equals 1 if a firm is either a new exporter or a continuing exporter. Column (2) includes four-digit (about 480) industry, ownership and province fixed effects. In Panel A, ln(TFP) is measured using the Levinsohn-Petrin (2003) method. In Panel B, real capital stock $(\mathrm{K})$ is measured using the perpetual inventory method specified in Brandt et al. (2011), while labor is the firm's total employment. In Panel C, capital stock is the net value of fixed assets deflated by the sector-specific capital-good deflator, while labor is the firm's total employment. In Panel D, capital stock is measured using the perpetual inventory method specified in Brandt et al. (2011), while labor is the firm's total wage bill. Columns (1) and (2) compare exporters and non-exporters using all firms in the sample; column (3) includes only domestic firms; column (4) includes only foreign-invested enterprieses (FIEs); column (5) and (6) split the sample into that before 2002 when China was accessed to the WTO; and that after and including 2002; column (7) includes only firm fixed ef Numbers reported in brackets are p-values corrected for four-digit industry clustering. *, **, and *** indicate significance at the $10 \%, 5 \%$, and $1 \%$ levels, respectively. 
Table 2: Capital Intensity Growth: New Exporters Less Non-Exporters

$\Delta \ln (K / L)_{\text {new exporter }}-\Delta \ln (K / L)_{\text {non-exporter }}$

\begin{tabular}{|c|c|c|c|c|c|}
\hline \multirow[t]{2}{*}{ Panel A } & & \multicolumn{4}{|c|}{$\ln (\mathrm{TFP})$ quartiles before exporting } \\
\hline & & 1 & 2 & 3 & 4 \\
\hline \multirow{4}{*}{$\begin{array}{l}\ln (\mathrm{K} / \mathrm{L}) \\
\text { quartiles } \\
\text { before } \\
\text { exporting }\end{array}$} & 1 & $-0.033 * * *$ & $-0.031 * * *$ & $-0.018 * *$ & $-0.002 *$ \\
\hline & 2 & $-0.045 * * *$ & $-0.039 * * *$ & $-0.026 * * *$ & $-0.019 * *$ \\
\hline & 3 & $-0.051 * * *$ & $-0.043 * * *$ & $-0.038 * * *$ & $-0.039 * * *$ \\
\hline & 4 & $-0.063 * * *$ & $-0.061 * * *$ & $-0.055 * * *$ & $-0.051 * * *$ \\
\hline \multirow[t]{2}{*}{ Panel B } & & \multicolumn{2}{|c|}{ low TFP } & \multicolumn{2}{|c|}{ high TFP } \\
\hline & & small firms & large firms & small firms & large firms \\
\hline $\begin{array}{c}\ln (\mathrm{K} / \mathrm{L}) \\
\text { before }\end{array}$ & low & $-0.035 * * *($ bin 1$)$ & $-0.039 * * *(\operatorname{bin} 2)$ & $-0.011 * *(\operatorname{bin} 3)$ & $-0.021 * *(\operatorname{bin} 4)$ \\
\hline exporting & high & $-0.056 * * *($ bin 5$)$ & $-0.053 * * *($ bin 6$)$ & $-0.049 * * *($ bin 7$)$ & $-0.043 * * *(\operatorname{bin} 8)$ \\
\hline
\end{tabular}

Notes: This table reports the difference of capital intensity growth between new exporters and non-exporters for each bin. In Panel A, bins are defined by $\ln (\mathrm{TFP})$ and $\ln (\mathrm{K} / \mathrm{L})$ quartiles. In Panel B, bins are defined by $\ln (\mathrm{TFP}), \ln (\mathrm{K} / \mathrm{L})$ and $\ln ($ sales $)$. We calculate these bins industry by industry to ensure each bin covers all industries. $* * *$, and $* * *$ indicate significance at the $10 \%, 5 \%$, and $1 \%$ levels, respectively. 
Table 3: New Exporters' Capital Intensity $\ln (\mathrm{K} / \mathrm{L})$ - Propensity Score Matching Results

\begin{tabular}{|c|c|c|c|c|c|c|c|}
\hline & & & (1) & (2) & (3) & (4) & (5) \\
\hline Bin & $\begin{array}{c}\mathrm{K} / \mathrm{L} \\
\text { Group }\end{array}$ & $\begin{array}{c}\text { TFP } \\
\text { Group }\end{array}$ & All Firms & $\begin{array}{c}\text { Domestic } \\
\text { Firms }\end{array}$ & $\begin{array}{c}\text { Foreign } \\
\text { Firms }\end{array}$ & Alternative $\mathrm{K}$ & Alternative L \\
\hline All Bins & & & $-0.051 * * *$ & $-0.054 * * *$ & $-0.042 * * *$ & $-0.027 * *$ & $-0.069 * * *$ \\
\hline 1 & & 至 & $-0.046 * * *$ & $-0.049 * * *$ & $-0.036 * * *$ & $-0.028 * * *$ & $-0.035 * * *$ \\
\hline 2 & $\stackrel{\vec{\Delta}}{\vec{\nu}}$ & $I$ & $-0.048 * * *$ & $-0.048 * * *$ & $-0.037 * * *$ & $-0.024 *$ & $-0.046 * * *$ \\
\hline 3 & ó & 突 & $-0.029 * *$ & $-0.031 * *$ & -0.029 & 0.001 & $-0.024 * * *$ \\
\hline 4 & & - & $-0.032 * *$ & $-0.041 * *$ & -0.027 & -0.009 & $-0.032 * * *$ \\
\hline 5 & & 乒 & $-0.064 * * *$ & $-0.067 * * *$ & $-0.061 * * *$ & $-0.044 * *$ & $-0.102 * * *$ \\
\hline 6 & $\stackrel{\vec{v}}{\vec{\nu}}$ & $I$ & $-0.061 * * *$ & $-0.066^{* * *}$ & $-0.053 * * *$ & $-0.029 *$ & $-0.113 * * *$ \\
\hline 7 & 氠 & 突 & $-0.063 * * *$ & $-0.068 * * *$ & $-0.051 * * *$ & $-0.043 * * *$ & $-0.096 * * *$ \\
\hline 8 & & 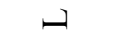 & $-0.059 * * *$ & $-0.062 * * *$ & $-0.61 * * *$ & $-0.039 * * *$ & $-0.103 * * *$ \\
\hline
\end{tabular}

Notes: This table reports the estimation results of the impact of exporting on $\ln (\mathrm{K} / \mathrm{L})$ for new exporters, using DID propensity score matching method. The matching is conducted within each bin. These bins (bin1 to bin 8) are illustrated in Panel B of Table 2. Column (1) uses all firms in the sample; column (2) includes only domestic firms; column (3) includes only foreign-invested enterprieses (FIEs); columns (4) measures capital stock as the net value of fixed assets deflated by the sector-specific capital-good deflator, while column (5) uses the firm's total wage bill to compute capital intensity. ${ }^{*}, * *$, and $* * *$ indicate significance at the $10 \%, 5 \%$, and $1 \%$ levels, respectively. 
Table 4: Ex ante Productivity and Ex post Capital Intensity

\begin{tabular}{lccc} 
& \multicolumn{2}{c}{ Dependent Variable $=\Delta \ln (\mathrm{K} / \mathrm{L})_{\text {non-exporter }}-\Delta \ln (\mathrm{K} / \mathrm{L})_{\text {new exporter }}$} \\
\hline \hline & All New Exporters & $\begin{array}{c}(2) \\
\text { Domestic New } \\
\text { Exporters only }\end{array}$ & $\begin{array}{c}\text { Foreign New Exporters } \\
\text { only }\end{array}$ \\
\hline $\ln (\mathrm{TFP})_{\mathrm{t}-1}$ & -0.096 & -0.132 & 0.021 \\
& {$[0.006]^{* * *}$} & {$[0.007]^{* * *}$} & {$[0.011]^{* *}$} \\
$\ln (\mathrm{K} / \mathrm{L})_{\mathrm{t}-1}$ & 0.298 & 0.345 & 0.276 \\
& {$[0.000]^{* * *}$} & {$[0.000]^{* * *}$} & {$[0.000]^{* * *}$} \\
$\ln (\text { wage rate })_{\mathrm{t}-1}$ & -0.188 & -0.193 & -0.198 \\
& {$[0.000]^{* * *}$} & {$[0.000]^{* * *}$} & {$[0.024]^{* *}$} \\
$\ln (\text { age })_{\mathrm{t}-1}$ & -0.029 & -0.035 & -0.027 \\
& {$[0.008]^{* * *}$} & {$[0.009]^{* * *}$} & {$[0.012]^{* *}$} \\
\hline Ownership FE & Yes & No & No \\
Industry FE & Yes & Yes & Yes \\
Province FE & Yes & Yes & Yes \\
\hline $\mathrm{N}$ & 49,742 & 33,409 & 16,333 \\
\hline \hline
\end{tabular}

Notes: All regressors are lagged by one year. Only new exporters are included in the regressions. Pvalues based on standard errors clustered at the four-digit industry are reported in brackets. *,**, and $* * *$ indicate significance at the $10 \%, 5 \%$, and $1 \%$ levels, respectively. Exporters and their matched non-exporters are matched using the DID propensity score matching techniques which is conducted within their own bins. 
Table 5: Determinants of the TFP effects

Dependent Variable $=\Delta \ln (\text { TFP })_{\text {new exporter }}-\Delta \ln (\text { TFP })_{\text {non exporter }}$

\begin{tabular}{lccc}
\hline \hline & $(1)$ & $(2)$ & $(3)$ \\
& All New Exporters & $\begin{array}{c}\text { Domestic New } \\
\text { Exporters only }\end{array}$ & $\begin{array}{c}\text { Foreign New Exporters } \\
\text { only }\end{array}$ \\
\hline labor intensity $_{\mathrm{t}-1, \mathrm{t}}$ & 0.049 & 0.055 & 0.022 \\
{$[0.000]^{* * *}$} & {$[0.005]^{* * *}$} & {$[0.022]^{* *}$} \\
$\ln (\mathrm{TFP})_{\mathrm{t}-1}$ & 0.121 & 0.135 & 0.119 \\
& {$[0.000]^{* * *}$} & {$[0.000]^{* * *}$} & {$[0.000]^{* * *}$} \\
$\ln (\text { wage rate })_{\mathrm{t}-1}$ & 0.087 & 0.093 & 0.076 \\
$\ln (\text { age })_{\mathrm{t}-1}$ & {$[0.000]^{* * *}$} & {$[0.002]^{* * *}$} & {$[0.002]^{* * *}$} \\
\hline Industry FE & -0.076 & -0.086 & -0.078 \\
Onwership FE & {$[0.009]^{* * *}$} & {$[0.013]^{* *}$} & {$[0.037]^{* *}$} \\
Province FE & Yes & Yes & Yes \\
\hline $\mathrm{N}$ & Yes & No & Yes \\
\hline \hline
\end{tabular}

Notes: All regressors are lagged by one year, besides labor intensity increase, which is defined as the first difference in labor intensity from year $\mathrm{t}-1$ to $t$. Only new exporters are included in the regressions. Pvalues, based on standard errors clustered at the four-digit industry level, are reported in brackets. *, **, and $* * *$ indicate significance at the $10 \%, 5 \%$, and $1 \%$ levels, respectively. 
Table 6: Product Switching of New Exporters (Customs Transaction-level Data)

\begin{tabular}{cccccc}
\hline \hline & $\begin{array}{c}\text { Number of new } \\
\text { exporters }\end{array}$ & $\begin{array}{c}\text { Number of new } \\
\text { exporters that } \\
\text { survived to next } \\
\text { year }\end{array}$ & $\begin{array}{c}\text { Total (average) } \\
\text { number of } \\
\text { products added } \\
\text { next year }\end{array}$ & $\begin{array}{c}\text { Total (average) } \\
\text { number of } \\
\text { products dropped } \\
\text { next year }\end{array}$ & $\begin{array}{c}\text { Total number of } \\
\text { continuing } \\
\text { products }\end{array}$ \\
\hline 2000 & 15,928 & 13,187 & $134059(10.17)$ & $56389(4.28)$ & $63929(4.85)$ \\
2001 & 21,383 & 18,410 & $176066(9.56)$ & $82096(4.46)$ & $98364(5.34)$ \\
2002 & 27,107 & 22,941 & $229762(10.02)$ & $127959(5.58)$ & $125753(5.48)$ \\
2003 & 37,646 & 31,583 & $322921(10.22)$ & $207112(6.56)$ & $161901(5.13)$ \\
2004 & 40,024 & 33,552 & $311839(9.29)$ & $265860(7.92)$ & $166894(4.97)$ \\
2005 & 46,400 & & & & \\
2006 & 31,415 & 23,935 & 9.85 & 5.76 & 5.15 \\
\hline Average & & & & & \\
\hline \hline
\end{tabular}

Source: Transaction-level trade data from China Customs (2000-2006)

Notes: A product is defined as a HS 6-digit category. There are over 5000 HS-6 categories. 
Table 7: Capital Intensity of New Products and Dropped Products

Dependent Variable: $\ln (\mathrm{K} / \mathrm{L})$

All New

\begin{tabular}{lcccccc} 
& $\begin{array}{c}\text { All New } \\
\text { Exporters }\end{array}$ & $\begin{array}{c}\text { Exporters } \\
\text { Excluding } \\
\text { Intermediaries }\end{array}$ & $\begin{array}{c}\text { New Ordinary } \\
\text { Exporters }\end{array}$ & $\begin{array}{c}\text { New Processing } \\
\text { Exporters }\end{array}$ & $\begin{array}{c}\text { Capital- } \\
\text { Abundant } \\
\text { Destinations }\end{array}$ & $\begin{array}{c}\text { Labor-Abundant } \\
\text { Destinations }\end{array}$ \\
\hline New Product Portfolio & -0.048 & -0.049 & -0.050 & -0.045 & -0.050 & -0.043 \\
Dummy & {$[0.000]^{* * *}$} & {$[0.000]^{* * *}$} & {$[0.000]^{* * *}$} & {$[0.000]^{* * *}$} & {$[0.000]^{* * *}$} & {$[0.000]^{* * *}$} \\
Dropped Product Portfolio & 0.023 & 0.021 & 0.024 & 0.013 & 0.022 & 0.023 \\
Dummy & {$[0.000]^{* * *}$} & {$[0.000]^{* * *}$} & {$[0.000]^{* * *}$} & {$[0.005]^{* * *}$} & {$[0.000]^{* * *}$} & {$[0.002]^{* * *}$} \\
Year Fixed Effects & Yes & Yes & Yes & Yes & Yes & 213,272 \\
\hline $\mathrm{N}$ & 326,784 & 281,035 & 252,887 & 73,897 & 42,987 \\
\hline \hline
\end{tabular}

Notes: This table reports the results of regressions of capital intensity on the new product portfolio dummy and the dropped product portfolio dummy. The omitted group is the continuing product portfolio. Column (2) excludes all trade intermediaries. Columns (3) and (4) use the subsamples of ordinary and processing trade new exporters. Column (5) and (6) use the subsamples of the exports to capital-abundant countries and labor-abundant countries. The classification of capital abundance is based on Antweiler and Trefler (2002). P-values, based on robust standard errors, are reported in brackets. *,**, and $* * *$ indicate significance at the $10 \%, 5 \%$, and $1 \%$ levels, respectively. 


\section{Appendix Tables (Not for publication)}

Table A1: New Exporter Information 1999-2007 (Odd years only)

\begin{tabular}{|c|c|c|c|c|c|c|c|c|c|c|}
\hline & \multicolumn{2}{|c|}{1999} & \multicolumn{2}{|c|}{2001} & \multicolumn{2}{|c|}{2003} & \multicolumn{2}{|c|}{2005} & \multicolumn{2}{|c|}{2007} \\
\hline & Domestic & Foreign & Domestic & Foreign & Domestic & Foreign & Domestic & Foreign & Domestic & Foreign \\
\hline Total no. of firms & 118,251 & 25,272 & 121,896 & 29,332 & 140,107 & 36,192 & 195,902 & 55,597 & 246,558 & 78,801 \\
\hline$\%$ & $100 \%$ & $100 \%$ & $100 \%$ & $100 \%$ & $100 \%$ & $100 \%$ & $100 \%$ & $100 \%$ & $100 \%$ & $100 \%$ \\
\hline Non-exporters & 97,079 & 9,209 & 96,944 & 9,534 & 107,578 & 10,954 & 156,325 & 20,786 & 208,027 & 26,220 \\
\hline$\%$ & $82 \%$ & $36 \%$ & $80 \%$ & $33 \%$ & $77 \%$ & $30 \%$ & $80 \%$ & $37 \%$ & $84 \%$ & $33 \%$ \\
\hline Continuing exporters & 18,394 & 14,742 & 23,383 & 18,442 & 30,128 & 23,616 & 31,088 & 32,759 & 33,504 & 49,773 \\
\hline$\%$ & $16 \%$ & $58 \%$ & $19 \%$ & $63 \%$ & $22 \%$ & $65 \%$ & $16 \%$ & $59 \%$ & $14 \%$ & $63 \%$ \\
\hline New exporters & 2,778 & 1,321 & 1,569 & 1356 & 2,401 & 1622 & 8,489 & 2,052 & 5,027 & 2,808 \\
\hline$\%$ & $2.3 \%$ & $5.2 \%$ & $1.3 \%$ & $4.6 \%$ & $1.7 \%$ & $4.5 \%$ & $4.3 \%$ & $3.7 \%$ & $2.0 \%$ & $3.6 \%$ \\
\hline \multicolumn{11}{|c|}{ Export intensity of new exporters (\%) } \\
\hline 0 to 10 & 35.9 & 25.2 & 41.1 & 35.1 & 38.9 & 33.8 & 58.1 & 36.0 & 46.2 & 36.1 \\
\hline 10 to 20 & 11.1 & 7.7 & 11.9 & 9.7 & 11.6 & 9.9 & 20.3 & 12.5 & 11.6 & 10.5 \\
\hline 20 to 30 & 7.2 & 5.1 & 6.6 & 9.2 & 7.8 & 5.3 & 3.8 & 6.2 & 5.8 & 5.9 \\
\hline 30 to 40 & 6.0 & 4.1 & 5.2 & 4.6 & 6.1 & 4.3 & 2.5 & 4.2 & 4.5 & 4.2 \\
\hline 40 to 50 & 6.2 & 6.0 & 3.9 & 2.8 & 5.1 & 4.0 & 2.1 & 4.0 & 3.5 & 3.9 \\
\hline 50 to 60 & 4.4 & 4.2 & 4.2 & 3.0 & 4.8 & 4.0 & 1.2 & 3.7 & 2.4 & 3.2 \\
\hline 60 to 70 & 5.3 & 4.7 & 3.3 & 2.4 & 4.3 & 4.2 & 1.2 & 3.1 & 2.3 & 2.9 \\
\hline 70 to 80 & 4.2 & 6.8 & 3.5 & 4.2 & 4.0 & 4.7 & 1.4 & 3.4 & 2.2 & 3.1 \\
\hline 80 to 90 & 5.7 & 7.6 & 5.3 & 4.9 & 3.7 & 4.9 & 1.4 & 2.8 & 2.2 & 3.5 \\
\hline 90 to 100 & 14.2 & 28.7 & 15.1 & 24.1 & 13.8 & 24.9 & 8.1 & 24.1 & 19.3 & 26.7 \\
\hline Sum & 100.0 & 100.0 & 100.0 & 100.0 & 100.0 & 100.0 & 100.0 & 100.0 & 100.0 & 100.0 \\
\hline
\end{tabular}

Source: China's National Bureau of Statistics industrial (above-scale) firm survey data. 
Table A2: The Decision to Start Exporting

Dependent variable: New-exporter indicator

\begin{tabular}{|c|c|c|}
\hline Probit estimation & Domestic firms & Foreign firms \\
\hline $\ln \mathrm{TFP}$ & $\begin{array}{c}0.113 \\
{[0.000]^{* * *}}\end{array}$ & $\begin{array}{c}0.002 \\
{[0.314]}\end{array}$ \\
\hline Wage per worker & $\begin{array}{c}0.030 \\
{[0.000]^{* * *}}\end{array}$ & $\begin{array}{c}0.008 \\
{[0.298]}\end{array}$ \\
\hline Capital/labor & $\begin{array}{c}-0.038 \\
{[0.000]^{* * *}}\end{array}$ & $\begin{array}{c}-0.031 \\
{[0.000]^{* * *}}\end{array}$ \\
\hline Age & $\begin{array}{c}-0.059 \\
{[0.000]^{* * *}}\end{array}$ & $\begin{array}{c}-0.119 \\
{[0.000]^{* * *}}\end{array}$ \\
\hline Sales & $\begin{array}{c}0.113 \\
{[0.000]^{* * *}}\end{array}$ & $\begin{array}{c}0.101 \\
{[0.001]^{* * *}}\end{array}$ \\
\hline $\begin{array}{l}\text { Industry FE } \\
\text { Provincial FE } \\
\text { Year FE }\end{array}$ & $\begin{array}{l}\text { Yes } \\
\text { Yes } \\
\text { Yes }\end{array}$ & $\begin{array}{l}\text { Yes } \\
\text { Yes } \\
\text { Yes }\end{array}$ \\
\hline $\begin{array}{l}\text { Pseudo R-squared } \\
\text { Observations }\end{array}$ & $\begin{array}{c}0.1032 \\
1,216,415\end{array}$ & $\begin{array}{c}0.0987 \\
150,328\end{array}$ \\
\hline $\begin{array}{l}\text { Notes: The dependent varia } \\
\text { to export. *, } * * \text {, and } * * * \text { in } \\
\text { respectively. All regression } \\
\text { values are in brackets, are } \\
\text { error, and are corrected for }\end{array}$ & $\begin{array}{l}\text { nmy variable indic } \\
\text { ficance at the } 10 \% \\
\text { full set of industry } \\
\text { ber-White heteros } \\
\text { ovince clustering. }\end{array}$ & $\begin{array}{l}\text { ear when a firm } \\
\% \text { levels, } \\
\text { and year dummi } \\
\text { consistent stand }\end{array}$ \\
\hline
\end{tabular}


Table A3: Propensity Score Matching Results of Capital Intensity $\ln (\mathrm{K} / \mathrm{L})(1999-2007)$

\begin{tabular}{|c|c|c|c|c|c|c|c|c|}
\hline 1999 & 2000 & 2001 & 2002 & 2003 & 2004 & 2005 & 2006 & 2007 \\
\hline \multicolumn{9}{|c|}{ Panel A: DID Matching } \\
\hline-0.086 & -0.054 & -0.051 & -0.017 & -0.055 & -0.077 & -0.051 & -0.061 & -0.071 \\
\hline$[0.053]^{*}$ & {$[0.048]^{* *}$} & {$[0.024]^{* *}$} & {$[0.152]$} & {$[0.020]^{* *}$} & {$[0.024]^{* *}$} & {$[0.031]^{* *}$} & {$[0.009]^{* * *}$} & {$[0.005]^{* * *}$} \\
\hline \multicolumn{9}{|c|}{ Panel B: Local Linear Regression Matching } \\
\hline-0.062 & -0.051 & -0.029 & -0.028 & -0.093 & -0.065 & -0.046 & -0.032 & -0.018 \\
\hline$[0.021]^{* *}$ & {$[0.030]^{* *}$} & {$[0.034]^{* *}$} & {$[0.066]^{*}$} & {$[0.014]^{* *}$} & {$[0.031]^{* *}$} & {$[0.035]^{* * *}$} & {$[0.009]^{* * *}$} & {$[0.087]^{*}$} \\
\hline \multicolumn{9}{|c|}{ Panel C: Nearest Neighbor Matching } \\
\hline-0.085 & -0.054 & -0.057 & -0.024 & -0.074 & -0.064 & -0.070 & -0.052 & -0.069 \\
\hline$[0.016]^{* *}$ & {$[0.040]^{* *}$} & {$[0.029]^{* *}$} & {$[0.046]^{* *}$} & {$[0.045]^{* *}$} & {$[0.011]^{* *}$} & {$[0.027]^{* *}$} & {$[0.012]^{* *}$} & {$[0.082]^{*}$} \\
\hline
\end{tabular}

Notes: This table examines the impact of exporting on capital intensity by year, using three different propensity score matching

methods to compare exporters' ex-post capital intensity with that of non-exporters. P-values, based on bootstrapped standard errors

are reported in brackets. *, ${ }^{*}$, and $* * *$ indicate significance at the $10 \%, 5 \%$, and $1 \%$ levels, respectively. 
Table A4: Information about merging the industrial firm survey (NBS) data with customs Data

\begin{tabular}{lcccc}
\hline \hline & $\begin{array}{c}\text { Num. of Exporters } \\
\text { in Customs Data }\end{array}$ & $\begin{array}{c}\text { Num. of Exporters in } \\
\text { NBS Data }\end{array}$ & $\begin{array}{c}\text { Num. of Matched } \\
\text { Firms }\end{array}$ & $\begin{array}{c}\text { Share of Matched Firms } \\
\text { in Total Export Value } \\
\text { Reported by Customs }\end{array}$ \\
\hline 2000 & 62,771 & 36,888 & 19,733 & 0.37 \\
2001 & 68,072 & 40,128 & 22,904 & 0.39 \\
2002 & 78,612 & 45,004 & 25,994 & 0.41 \\
2003 & 95,629 & 50,594 & 29,789 & 0.42 \\
2004 & 120,589 & 76,593 & 46,010 & 0.49 \\
2005 & 144,030 & 74,388 & 48,552 & 0.47 \\
2006 & 171,205 & 78,206 & 52,324 & 0.45 \\
\hline \hline
\end{tabular}

Notes: Firms from the two date sets are merged by firm names and other information. The first column lists the number of exporters reported in the customs data set; the second column lists the number of exporters reported in the NBS firm data. The numbers are consistently larger in the second column because the customs data set covers the universe of exporters, including trade intermediary firms. The NBS data set includes the above-scale firms that have over 5 million RMB sales revenue in the sample year. The third column reports the number of merged firms. The last column reports the share of exports attributable to the matched firms. 
Table A5: An Example of HS-6 Products within an Industry

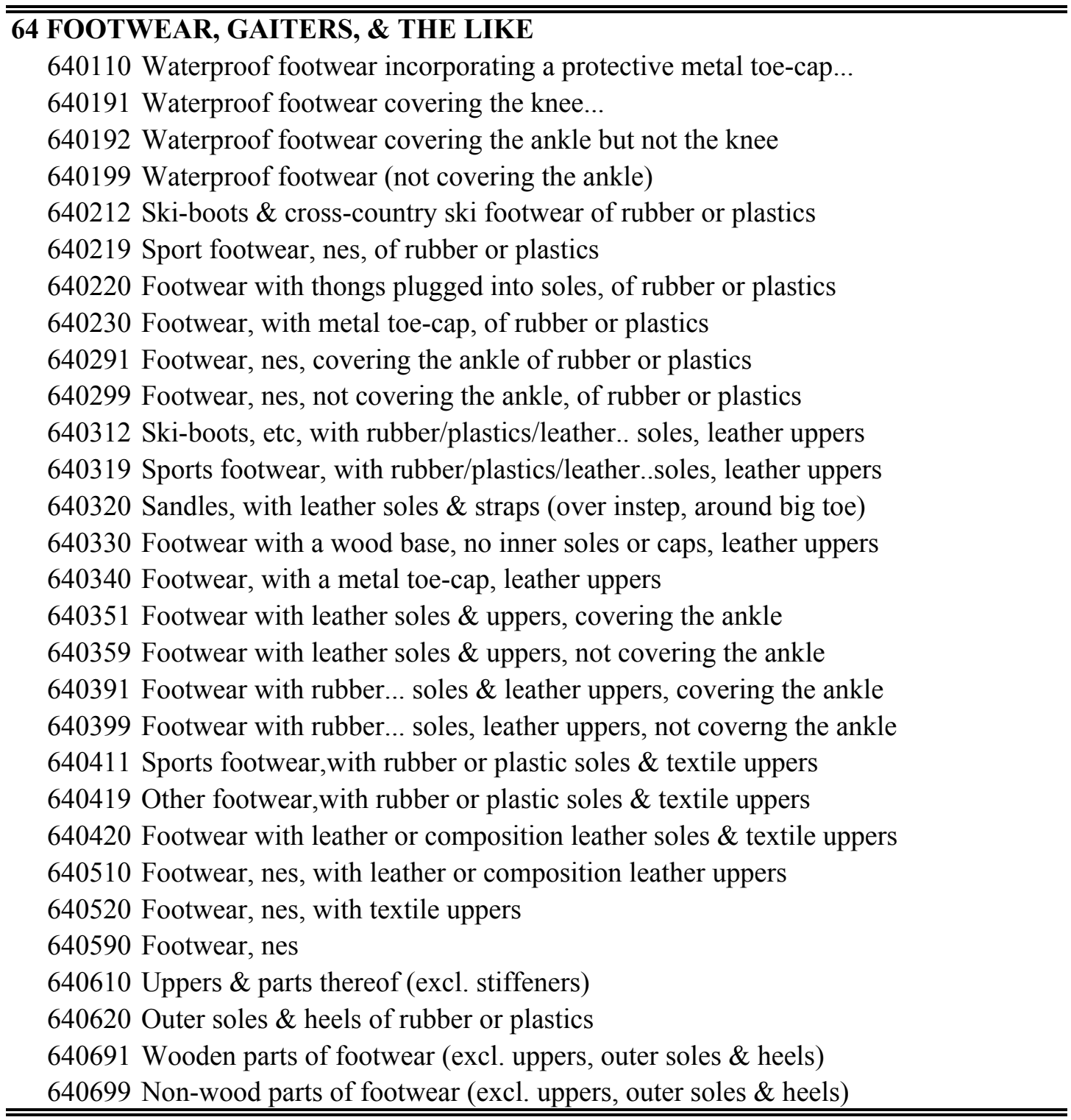


Table A6: Capital Intensity by Sector (2001)

\begin{tabular}{lcccc}
\hline \hline \multicolumn{1}{c}{ Sector } & $\begin{array}{c}\text { HS 2-digit } \\
\text { codes }\end{array}$ & $\begin{array}{c}\text { Num. of HS-6 } \\
\text { products }\end{array}$ & $\begin{array}{c}\text { Capital Intensity } \\
\text { (mean) }\end{array}$ & $\begin{array}{c}\text { Capital Intensity } \\
\text { (St Dev) }\end{array}$ \\
\hline Animals \& Animal Products & $01-05$ & 174 & 70.9 & 56.9 \\
Vegetable Products & $06-14$ & 254 & 71.8 & 61.1 \\
Animal Or Vegetable Fats & 15 & 35 & 64.9 & 63.3 \\
Prepared Foodstuffs & $16-24$ & 173 & 94.6 & 69.0 \\
Mineral Products & $25-27$ & 134 & 90.1 & 70.9 \\
Chemical Products & $28-38$ & 764 & 111.6 & 66.5 \\
Plastics \& Rubber & $39-40$ & 198 & 79.6 & 65.2 \\
Hides \& Skins & $41-43$ & 62 & 45.5 & 47.0 \\
Wood \& Wood Products & $44-46$ & 75 & 62.3 & 56.5 \\
Wood Pulp Products & $47-49$ & 147 & 93.7 & 66.8 \\
Textiles \& Textile Articles & $50-63$ & 818 & 68.1 & 54.9 \\
Footwear, Headgear & $64-67$ & 55 & 27.8 & 43.0 \\
Articles Of Stone, Plaster, Cement, Asbestos & $68-70$ & 147 & 72.2 & 64.9 \\
Pearls, Precious Or Semi-Precious Stones, Metals & 71 & 41 & 32.1 & 59.5 \\
Base Metals \& Articles Thereof & $72-83$ & 563 & 93.9 & 63.5 \\
Machinery \& Mechanical Appliances & $84-85$ & 792 & 99.2 & 63.9 \\
Transportation Equipment & $86-89$ & 121 & 107.2 & 66.8 \\
Instruments - Measuring, Musical & $90-92$ & 235 & 99.6 & 62.8 \\
Arms \& Ammunition & 93 & 10 & 152.4 & 69.9 \\
Miscellaneous & $94-96$ & 130 & 47.8 & 51.5 \\
Works Of Art & $97-99$ & 9 & 53.2 \\
\hline \hline
\end{tabular}

Notes: The unit is throusand yuan (RMB) per worker. We estimate the capital intensity of HS6 products using the merged data set. This table shows the summary statistics of capital intensity by broad sectors. See Appendix A.3 for the procedure to compute capital intensity at the HS 6-digit level. 